\title{
Competition and Contracts in the Nordic Electricity Markets
}

Stephen Littlechild

November 2005

CWPE 0550 and EPRG 06

These working papers present preliminary research findings, and you are advised to cite with caution unless you first contact the author regarding possible amendments. 


\title{
Competition and contracts in the Nordic residential electricity markets
}

\author{
Stephen Littlechild \\ 14 September 2005
}

\begin{abstract}
The main Nordic residential electricity markets (Norway, Sweden and Finland) effectively opened to retail competition around 1998. They have not been subject to regulatory controls on prices or other contract terms. Competition is developing well. Between 11 and 29 per cent of residential customers have switched to alternative suppliers. Between a fifth and a half of all residential customers have voluntarily chosen alternative contractual terms of supply, with either an alternative supplier or their local supplier. These alternatives include fixed price contracts ranging from 3 months to five years duration, as well as spot-price related terms, instead of the standard variable tariffs. The use of these alternatives is increasing over time, and there is considerable product innovation. This paper surveys these developments and illustrates with case studies of significant suppliers in each Nordic market. The market is thus ascertaining and bringing about the outcomes that customers prefer. If markets are not open to retail competition, it is not clear how regulation will replicate this aspect of the market process.
\end{abstract}

Key words: retail competition, electricity, regulation, Nordic countries

JEL classifications: L94 electric utilities, L 14 transactional relationships and contracts, L51 economics of regulation.

\footnotetext{
* Professor Emeritus, University of Birmingham, and Senior Research Associate, Judge Business School, University of Cambridge. I am grateful to Ofgem for supporting visits to Sweden in June 2003 and to Norway, Finland and Sweden in March 2005. Many people have very helpfully provided information and comments, including Margareta Bergstrom, Hakan Heden and Andreas Nilssen (Swedish Energy Agency STEM), Kaj Forsberg and Peter Fritz (EME Analysis), Jan-Erik Moreau (LO), Johan Ohnell (Telge Energi), Jens Storm and Christina Svalstedt (Vattenfall), and Asa Hedstrom (TEMO) in Sweden; Lars Fosse, Christian Giswold, Trond Ljogodt, Jan Moen and Jon Sagen (NVE), Einar Westre (EBL), and Tove Pettersen and Kari Thorud (Hafslund) in Norway; Antti Paananen, VeliPekka Saajo and Asta Sihvonen-Punkka (Energy Market Authority), Ilkka Salonen (Vattenfall), Jukka Niemi (Helsinki Energy), Timo Karttinen, Jukka Ruusunen and Jaakko Tusa (Fortum), and Paivi Aaltonnen and Pekka Salomaa (Finish Energy Industries) in Finland; and a referee. None of the above is responsible for the views expressed herein.
} 


\subsection{Introduction}

There has been considerable discussion about the merits or otherwise of retail competition for residential electricity customers. Evidence has been drawn almost entirely from the UK and US. ${ }^{1}$ There is, however, another set of markets that were effectively opened to retail competition at the residential level around 1998, at about the same time as the UK market, namely, the three main Nordic electricity markets (Norway, Sweden and Finland). They can therefore provide some useful evidence on the possible performance and contribution of such markets.

The electricity sectors in these three countries were reformed over the period 1991 to 1996. With some qualifications, these reforms have been regarded as successful. ${ }^{2}$ Of particular interest for present purposes is that the Nordic markets were not subject to regulatory controls on prices or other contract terms. Retail competition has developed well in all three markets. The proportion of customers switching to alternative suppliers is lower than in the UK but generally higher than in other countries. An especially interesting feature of the Nordic markets is that a significant proportion of residential customers has actively chosen terms of supply other than the standard variable tariff. The chosen alternatives include fixed prices for defined periods of time, and prices explicitly linked to the NordPool spot price.

The paper begins with a brief account of the structure and regulatory framework of the Nordic markets generally. It then examines the origins, nature and estimated extent of these alternative contracts, taking each Nordic market in turn. It also illustrates with case studies of significant suppliers in each market. A final section summarises and concludes.

The paper does not attempt a full appraisal of the costs and benefits of retail competition. For example, it does not have access to data on costs of IT and marketing, nor on retail margins. Nevertheless, it hopefully adds an additional dimension to the debate, which has hitherto focused almost entirely on the price of a standardised product.

An Appendix summarises the main physical and market characteristics of these Nordic markets and their regulatory frameworks. There is some limited comparison with the UK, which in some ways is a benchmark for residential retail competition

\footnotetext{
${ }^{1}$ On the UK see for example Green and McDaniel (1998), Salies and Waddams Price (2004), Giulietti et al (2004, 2006), Davies et al (2005), Green (2005) and Newbery (2006). On the US and more generally see Joskow (2000a,b, 2005, 2006) and Tschamler (2006), and on Texas see Baldick and Niu (2006) and Adib and Zarnikau (2006). My own writings on this topic include Littlechild (2001a,b, 2002, 2003a,b, 2004, 2005a,b). The volumes edited by Glachant and Finon (2003), Griffin and Puller (2005) and Sioshanshi and Pfaffenburger (2006) also contain some discussion of retail competition in other countries. Von der Fehr et al $(2005,2006)$ discuss retail competition and contracts in the Nordic countries, but mainly for the light that it sheds on the extent of competition generally, especially in Sweden versus Norway.

${ }^{2}$ E.g. Bergman (2002, 2005), Hjalmarsson (2002), Amundsen and Bergman (2003), Swedish Energy Agency (2004) (henceforth STEM 2004), von der Fehr et al (2005, 2006). The present paper does not cover the Danish market, which linked up with the other Nordic markets somewhat later and has not been at the forefront of retail competition.
} 


\subsection{Nordic market opening and the retail regulatory framework}

Electricity deregulation and reform began in Norway in 1991, followed by Finland and Sweden in 1995/96. In all three countries, retail competition at the residential level was not effective at first because customers were required to install a new meter to measure consumption on an hourly basis, and the cost of this was largely prohibitive. ${ }^{3}$ Only after the introduction of profiling did retail competition become feasible for residential customers. This happened in the period 1997 to 1999, at about the same time as the residential market opened (with profiling) in the UK.

The high electricity consumption of Nordic households - some two to four times the UK and OECD average - provides an incentive for such customers to take an active interest in the market. The generation context is at first sight not conducive to retail competition, since the largest company in each country, typically state-owned, accounts for about 40 to 50 per cent of total generation (taking account of extensive cross-ownership). But the commonly accessed NordPool spot and forwards markets provide some counterweight to this (see Appendix).

The Nordic regulatory framework is conducive to retail competition, at least within each country. ${ }^{4}$ In all three countries there is regulated third party access to transmission and distribution networks (as in most European countries except Germany). Although vertical integration is common, there is a high degree of accounting, management, legal and ownership separation of generation, transmission, distribution and supply. ${ }^{5}$

In none of the Nordic countries have there been controls on prices, either before or after liberalisation. This may reflect the extent of public ownership, both by the national states and by municipalities.

In other respects, too, regulation of the competitive retail market is relatively light and simple, especially in Norway and Sweden. Incumbent suppliers are typically required to offer to customers within their area a standard tariff that is variable at two weeks' notice (four weeks in Finland). Customers can leave tariff this by giving due notice, generally without a fee (albeit with some restrictions in Finland). These suppliers can and do offer other kinds of contract, such as fixed term contracts or spot price contracts. Customers can change easily from a distribution company's standard tariff to a fixed-term or spot price contract with the same distribution company, typically within a day or two. Apart from a short compulsory 'cooling off period' applying to

\footnotetext{
${ }^{3}$ Thus in Sweden, "For a household, the cost was around EUR 1000. Later on, the network companies were obliged to install the required type of meter at a maximum cost of EUR 270." (Bergman 2002, fn 22, p. 32)

${ }^{4}$ Von der Fehr et al $(2005,2006)$ note some obstacles to transactions between suppliers in one country and customers in another, which may partly account for price differences between the Nordic countries. ${ }^{5}$ Norway was once judged to have the highest liberalisation indicators (competition and noncompetition) of seven leading countries in Europe, just ahead of the UK. Sweden and Finland were recorded as having similar characteristics. Energy Liberalisation Indicators in Europe, a consultation paper based on a study carried out by Oxera for the Governments of the UK and the Netherlands. October 2000.
} 
contracts generally, there are no constraints on the prices or other contract terms that suppliers can offer outside their own areas. ${ }^{6}$

Unlike the UK, distribution companies rather than retail suppliers are responsible for metering and meter reading, and there is no competition in metering services. Nordic regulators have seen no need for any regulatory check of companies' data processing systems or for accreditation of new suppliers or service providers. In contrast, such checking and accreditation has been expensive and time consuming in the UK. ${ }^{7}$

The basic Nordic model is two bills, one for supply and one for the local distribution grid. In practice the vertically integrated companies often combine these into one bill for their own customers. There is provision for the grid company to bill other suppliers on request so that these suppliers too can send one bill to their customers. This option is not much used in Norway since the local grid companies are accustomed to bill customers for broadband and other products. In Finland there is an extra charge to the customer for this option, and discussions are underway between the companies to resolve the issue. ${ }^{8}$

\subsection{Retail supply characteristics of the Nordic markets}

When the Nordic markets first opened there were over 600 different suppliers in total. Most of these were relatively small regional and municipal utilities. Since then there has been considerable consolidation, with the largest companies taking over the middle-sized as well as smaller ones. The total number of suppliers has roughly halved, so in total there are still about 300 suppliers. However, about two thirds of these companies do not offer supply outside their traditional geographic areas within their own country. Table 1a shows that between 30 and 80 suppliers are regarded as national suppliers in each country.

$\underline{\text { Table 1a Supply competition in the Nordic electricity markets. }}$

\begin{tabular}{|c|c|c|c|c|}
\hline Country & Norway & Sweden & Finland & $\begin{array}{r}\text { Great } \\
\text { Britain }\end{array}$ \\
\hline eregulation begins & 1991 & 1996 & $1995 / 6$ & 1990 \\
\hline Residential retail market & $1997 / 8$ & 1999 & 1998 & $1998 / 9$ \\
\hline
\end{tabular}

effectively open

\footnotetext{
${ }^{6}$ This contrasts with the UK, where there is a requirement that residential customers must be able to terminate any energy contract at 28 days' notice. UK suppliers must also offer a variety of payment methods. Littlechild (2005a,b) and discussion in the Conclusions below.

${ }^{7}$ The UK seems to be the exception internationally in terms of competition in metering services. At present, accreditation can cost about $£ 0.25$ million and take some 2 to 3 months in the UK. Elexon has suggested some possibilities for simplification and reform. Littlechild (2005a)

${ }^{8}$ Accuracy and frequency of meter-reading has been an issue in many countries. Sweden is taking some steps to improve investment here. "In order to facilitate supplier changes and give electricity customers a more direct connection between consumption and billing, the government [of Sweden] has passed a decision [in 2003] to introduce monthly metering of electricity usage among all electricity customers by 1 July 2009. Within the given timeframe, the network companies are free to decide the pace of implementation. The cost of the reform is estimated at around SEK 10 billion and will be paid for by the end consumers." The Electricity Year 2003, Swede Energy, p. 7. This represents about US\$300 per household. Some companies in Norway have urged similar investment. NVE recommends that all distribution companies should offer to provide two-way communication at a fixed rate, and encourages a step-by-step development, but is not convinced that a total implementation would be economic at present.
} 
Number of suppliers

$\begin{array}{lrrrr}\text { c } 1996 & >150 & 250 & 117 & 14 \\ \text { c } 2004 / 5 \text { total } & 130 & 126 & 70 & 10-15 \\ \text { c } 2004 / 5 \text { national } & 30 & 79 & 40 & 10-15\end{array}$

Source: Lewis et al 2004, Fosse 2005 and reports and information from regulatory bodies.

The large national generating companies, that often supply most customers, were and still are mostly publicly owned, although foreign ownership is increasing. ${ }^{9}$ In all three Nordic markets, the largest three or four integrated companies supply between a half and two thirds of the total market, as well as the majority of generation. Thus, in Sweden the Big Three companies (Vattenfall, Sydkraft and Fortum) account for about 86 per cent of generation and about 70 per cent of end-customer sales. ${ }^{10}$

Table $1 \mathrm{~b}$ Market concentration in Nordic electricity supply markets

\begin{tabular}{|l|r|r|r|r|}
\hline Country & Norway & Sweden & Finland & Great Britain \\
\hline Total market (generally by kWh) & $30-40$ & $25-35 ?$ & $?$ & 25 \\
\hline Largest supplier & $50-60$ & 70 & $30-35^{11}$ & 60 \\
\hline Largest 3 suppliers & $60-65$ & $>70$ & $>35$ & $85-90$ \\
\hline Largest 6 suppliers & $20-25$ & $>>13$ & $15-20 ?$ & 22 \\
\hline \multicolumn{5}{|l|}{ Residential sector (generally by customers) } \\
\hline Largest supplier & 35 & $?$ & $35-40 ?$ & 59 \\
\hline Largest 3 suppliers & $45-50$ & $?$ & $55-60 ?$ & 99 \\
\hline Largest 6 suppliers &
\end{tabular}

Source: Lewis et al 2004, Fosse 2005 and reports and information from regulatory bodies.

Although estimation of market shares is difficult because of cross-ownership, the residential sector seems less concentrated than the market as a whole, particularly compared to the UK. Retailers other than the largest six suppliers account for between a quarter and a half of the Nordic residential sectors compared to less than 1 per cent in the UK.

Even the largest Nordic companies are relatively small in terms of their customer numbers. British Gas Centrica, now the largest UK residential electricity supplier, has as many customers as the total number of electricity customers in all of Sweden. The other five major UK electricity suppliers have more customers each than the total number of customers in Norway or Finland. Nevertheless, in all three Nordic

\footnotetext{
${ }^{9}$ Vattenfall and Statkraft are $100 \%$ state owned in Sweden and Norway, respectively. Fortum is a quoted company on the Helsinki stock exchange, with the Finnish state owning nearly 60 per cent. Sydkraft was formerly quoted on the Stockholm stock exchange; it was delisted in May 2001 and is now 55\% owned by the German company E.ON and 44.6\% owned by Statkraft. "Between 1996 and 2001, foreign ownership of Swedish power generators increased from 13 to 40 per cent." (STEM 2004, p.19) See also Midttun et al 2003.

10 "When the electricity market was deregulated, seven companies accounted for 90 per cent of the power generated in Sweden. Today, three companies account for 86 per cent." The 2003 shares of these Big Three companies and their associates (via minority ownership and partnership) were Vattenfall 46.5\%, Sydkraft 20.5\% and Fortum 24.7\%. Shortly afterwards Sydkraft purchased Graninge 1.8\%. STEM 2004, p. 19, and p. 21 for retail sales. See also Lewis et al 2004.

${ }^{11}$ The percentage in Finland refers to total supply through the distribution network, excluding very large industrial users (forest industry) that buy in the wholesale market and account for about half of total electricity consumption in Finland.
} 
countries, not only the main suppliers but also some of the (even) smaller municipal suppliers have been active and effective retail competitors.

\section{THE RETAIL ELECTRICITY MARKET IN SWEDEN}

\subsection{The development of residential competition and contracts in Sweden}

Traditionally, incumbent electricity suppliers offered only a standard tariff, variable at short notice. This would have some reference to NordPool prices, but many suppliers priced with reference to their own generation. In consequence, standard variable tariff prices generally followed spot prices, but they were higher, smoother and somewhat lagged. Spot price during 1997 to 2000 was generally lower than it had been in previous years, which left average standard tariff price more than double the average spot price over this period. Spot prices rose in 2001 and 2002, then peaked sharply in winter of 2002/3 after the exceptionally dry year 2002 (Figure 1). During January 2003, when spot price was about five times its usual level, standard tariff prices were actually below spot price (see Table 2 ).

\section{Figure 1 NordPool spot price 1998-2003}

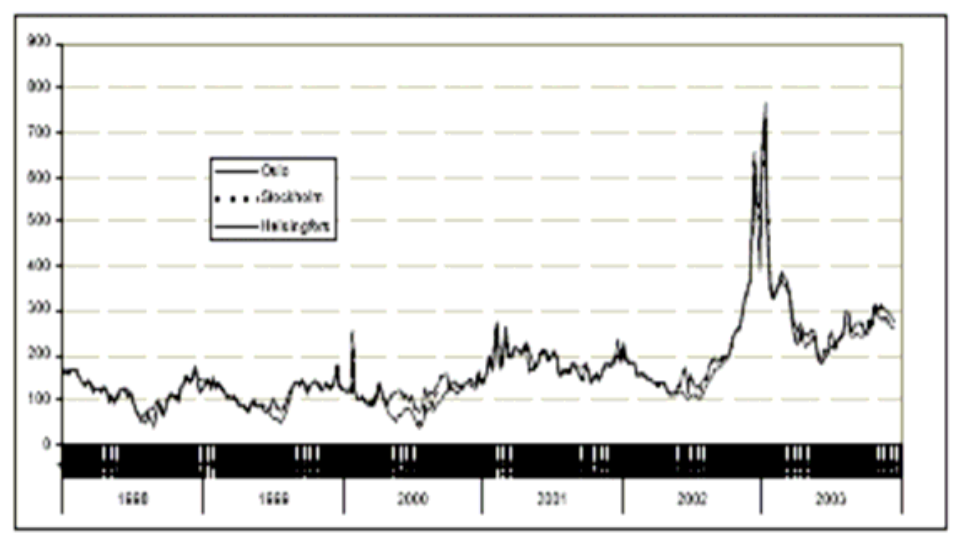

Figure 3. Twhiy a crage for Nord Pool's spot price, Heisiniti, Osio and Stocthoim. NOKMTh Solace: Nord Pooi ASA

One competitor began to offer fixed price fixed-term contracts from mid-1997 onwards (see section 2.3.1 below), but it was not until the metering requirement was relaxed that competition became active more widely. Contract prices generally undercut standard tariff prices, initially by up to $30 \%$ but in later years by less than that. ${ }^{12}$ Competitors also offered spot price contracts with a fixed margin added to cover costs. Gradually the incumbents responded by offering similar contracts, including to their own customers. So-called "active customers" comprise those that have switched supplier plus those that have changed from tariff to contract while staying with their local supplier.

Table 2 Typical energy charges in Sweden over time (ore/kWh as at 1 January)

\begin{tabular}{llllllllll}
\hline & 1996 & 1997 & 1998 & 1999 & 2000 & 2001 & 2002 & 2003 & 2004 \\
\hline Spot price (1 & 20.0 & 20.3 & 16.3 & 13.6 & 15.2 & 16.9 & 19.8 & 51.4 & 24.7 \\
\hline
\end{tabular}

\footnotetext{
${ }^{12}$ Contract prices have occasionally been below spot prices but above tariff prices, as in winter 2002/3 when tariff prices lagged behind the sharp rise in spot market prices.
} 


\begin{tabular}{|c|c|c|c|c|c|c|c|c|c|}
\hline January) & & & & & & & & & \\
\hline Spot price (yr) & 25.1 & 13.3 & 11.4 & 11.3 & 11.5 & 18.4 & 20.6 & 28.9 & 23.5 \\
\hline Standard tariff & 26.7 & 27.6 & 26.8 & 26.3 & 23.4 & 24.2 & 31.6 & 47.1 & 50.7 \\
\hline $\begin{array}{l}\text { Fixed price } \\
\text { contract }\end{array}$ & & & & 19 & $18-21$ & $21-30$ & $28-52$ & $52-40$ & $?$ \\
\hline
\end{tabular}

Source: mainly SCB

Regular consumer surveys by the organisation TEMO provide information about the behaviour of customers in Sweden (Table 3). According to these surveys, in 2000 nearly twice as many customers had changed to a contract with their local supplier as had switched to another supplier. But the number of switchers increased more rapidly. By October 200429 per cent of customers had switched supplier compared to 25 per cent that had changed to a contract with their existing supplier. Over half the consumers in Sweden are now 'active' in one way or another.

Table 3 Estimated proportions of active residential customers in Sweden (\%)

Switched to new supplier

Signed contract with local supplier

Total active customers

\begin{tabular}{lllll}
2000 & 2001 & 2002 & 2003 & 2004 \\
\hline 10 & 13 & 18 & 23 & 29 \\
18 & 17 & 17 & 22 & 25 \\
\hline 28 & 30 & 35 & 45 & 54 \\
72 & 70 & 65 & 55 & 46 \\
100 & 100 & 100 & 100 & 100
\end{tabular}

Total customers

Source: TEMO ${ }^{13}$

Over the last year, the Central Bureau of Statistics (SCB) in Sweden has begun to collect and publish data based on returns by distribution companies. ${ }^{14}$ These suggest that the above survey figures may overstate the proportion of active customers. According to SCB figures (see Table 5b below), in May 2004 customers still on the standard tariff took 56.8 per cent of residential electricity. It is not impossible that customers on the standard tariff have a higher average consumption than active consumers, but the opposite seems more likely. In any event, by May 2005 consumers on standard tariffs took only 49.6 per cent of residential electricity, so it is still the case that about half the residential consumers in Sweden are now 'active'.

With this qualification in mind, the TEMO surveys provide further interesting insights. Table 4 shows that customers in the three major cities are more likely to switch supplier than customers in other areas. Customers in rural areas are more likely to sign contracts with existing suppliers. The degree and nature of activity in the retail market is also related to size of electricity bill. Just as industrial customers are more active than residential, so too larger households are more active than small. Customers in houses are more likely to be active than those in apartments. They are more than twice as likely to sign contracts with existing suppliers than are customers in apartments. ${ }^{15}$ There are fewer such variations in the UK. ${ }^{16}$

\footnotetext{
${ }^{13}$ TEMO 2004, slides 22, 23, 30, 38, taking latest available data for each year. This is the source of the data for 2000 and 2003 reported in STEM 2004. These data are based on interviews with a sample of 1000 customers. See also comment in text re SCB figures.

${ }^{14} \mathrm{http}: / /$ www.scb.se/templates/tableOrChart 92219.asp

15 The lower proportion in apartments may reflect lower potential savings from lower usage, or rental versus ownership, or the predominance of district heating in apartments in urban areas. There is
} 
Table 4 Switching by customer type in Sweden October 2004

\begin{tabular}{llll}
\hline Customer type & $\begin{array}{l}\text { Switched } \\
\text { supplier \% }\end{array}$ & $\begin{array}{l}\text { Contract with } \\
\text { existing supplier \% }\end{array}$ & Total active \% \\
\hline Overall total 2004 & 29 & 25 & 54 \\
& & & 61 \\
In Stockholm, & 38 & 23 & 50 \\
Gothenburg, Malmo & & & 61 \\
In other cities & 25 & 25 & 61 \\
In rural areas & 26 & 35 & 39 \\
Houses & 30 & 31 & \\
Apartments & 26 & 13 & \\
\hline
\end{tabular}

Source: TEMO 2004 slide 24

About 42 per cent of customers that have changed supplier say it was difficult to compare prices. However, only about 11 per cent say that it was complicated to switch. ${ }^{17}$ About 87 per cent say that they are content with how the switch worked. These percentages have remained broadly constant over the last four years. There has been a gradual increase in the proportion of customers that have switched supplier twice (now up to 26 per cent of those who have ever changed supplier) and some have switched three or more times (now up to 9 per cent). Reasons given by those who had not been active were lack of interest (about 16\%), too little gain (14\%), too complicated (12\%), live in an apartment (12\%), use so little electricity $(6 \%)$, hard to choose (3\%) and 'other answers' (37\%). About 20 per cent of these inactive customers were intending to change supplier or thought they might do so. ${ }^{18}$

Table 5a shows that customers have chosen a variety of different products. The TEMO survey suggests that spot contracts and one-year fixed-price contracts have been more popular with customers who switched supplier; two- and three-year fixedprice contracts have been more popular with customers who stayed with their existing supplier. From 2001 to 2004 there has been a reduction in the proportion of customers on spot price and one year contracts, and an increase in the proportion on three-year contracts. In fact, nearly half of the customers that signed contracts with their existing supplier have chosen contracts for three years or longer. The final two columns of Table 5a are my own attempt to estimate the overall picture by a weighted average of the replies from switchers and non-switchers.

evidence that customers in houses with electric heating are more active than customers in houses without electric heating.

${ }^{16}$ Ofgem (2004 p. 188) has found that relative prices are important determinants of switching, and that the largest suppliers particularly British Gas are better able to attract customers, but that "customers in all social groups, across all incomes and of all ages are switching supplier at rates at or near the national average of 51 per cent in electricity and 41 per cent in gas". It reports no difference by type of housing tenure.

${ }^{17}$ In the UK, comparing prices is not perceived as difficult: $69 \%$ said it was fairly or very easy. The view about ease of switching is the same: $83 \%$ found it fairly or very easy. Even $61 \%$ of those that have never switched thought it would be fairly or very easy. Ofgem 2004, pp. 37-41.

${ }^{18}$ TEMO 2004 slides 32, 33, 44, 45. There is a similar variety of explanations in the UK. 
Table 5a Nature of contracts signed by customers: survey data

\begin{tabular}{llllllll}
\hline $\begin{array}{l}\text { Type of } \\
\text { contract }\end{array}$ & \multicolumn{3}{l}{ Those switching supplier \% } & \multicolumn{2}{l}{$\begin{array}{l}\text { New contract with } \\
\text { present supplier } \%\end{array}$} & Estimated total \% \\
\hline Date & Aug & Aug & Oct & Aug & Oct & Aug & Oct \\
& 2000 & 2001 & 2004 & 2001 & 2004 & 2001 & 2004 \\
Spot & 15 & 18 & 13 & 10 & 3 & 13 & 8 \\
$\leq 1$ year & 24 & 26 & 26 & 27 & 15 & 27 & 21 \\
2 years & 15 & 13 & 17 & 21 & 23 & 18 & 20 \\
$\geq 3$ years & 10 & 18 & 28 & 29 & 48 & 24 & 37 \\
Other & 36 & 25 & 16 & 13 & 11 & 18 & 14 \\
Total & 100 & 100 & 100 & 100 & 100 & 100 & 100 \\
\hline
\end{tabular}

Source: TEMO 2004 slides 34, 40

Table $5 \mathrm{~b}$ provides recent data from SCB for the country as a whole, based on usage rather than customer numbers. These data may be more accurate than the TEMO customer data, but the two data sets are broadly consistent if the TEMO 'unknown' category is included in the SCB 1 year category. On this basis, it appears that 1 year and 3-year contracts presently account for about three quarters of all contracts chosen by Swedish residential consumers.

Table 5b Nature of contracts signed by customers: statistics bureau (SCB) data

\begin{tabular}{lllll}
\hline $\begin{array}{l}\text { Terms of } \\
\text { supply }\end{array}$ & May 2004 & & May 2005 & \\
\hline & $\begin{array}{l}\text { All customers } \\
\%\end{array}$ & $\begin{array}{l}\text { Active } \\
\text { customers } \%\end{array}$ & $\begin{array}{l}\text { All customers } \\
\%\end{array}$ & $\begin{array}{l}\text { Active } \\
\text { customers \% }\end{array}$ \\
\hline Standard tariff & 56.8 & --- & 49.6 & --- \\
Spot price & 3.7 & 8.5 & 4.0 & 7.9 \\
1 year & 15.1 & 35.0 & 19.9 & 39.5 \\
2 years & 7.9 & 18.3 & 9.8 & 19.4 \\
3 years & 16.5 & 38.2 & 16.7 & 33.1 \\
Total & 100 & 100 & 100 & 100 \\
\hline
\end{tabular}

\subsection{Range of prices on offer in Sweden}

Once competitive offers began, many of the retail suppliers responded. The consumer authority maintains a website search organisation for electricity offers. ${ }^{21}$ This gives some indication of the extent of the market and how it has evolved over time.

In June 2003 the website listed 62 offers for a 3-year contract for a 20,000 kWh house with electric heating. The highest price (excluding grid charges) was offered by one of the Swedish Big Three companies. The saving of the best contract compared to the contract of the incumbent (another of the Big Three) was about $5 \%$ of total price. The

\footnotetext{
${ }^{19}$ Estimated by weighting the percentages in the previous columns by the reported proportions of customers in each category viz 13\% switched and 17\% new contracts with existing suppliers in August $2001,29 \%$ and $25 \%$ respectively in October 2004.

20 "Other" is the difference between $100 \%$ and the sum of the specified categories. Essentially, these are customers who 'don't know' or 'won't say'.

${ }^{21}$ www.kopguiden.konsumentverket.se. The organisation provides the site and invites suppliers to enter terms; it does not check those terms.
} 
main savings were in moving from a Standard tariff to a contract, rather than in finding the best contract. ${ }^{22}$

Table 6 (from another source) shows some tariff and contract prices on offer at that time for a medium consumption household. The source contained data for the 20 largest companies that account for some 80 per cent of electricity supply in Sweden. The average energy charge for a 1-year contract was nearly 20 per cent lower than the Standard tariff. The average energy charge for a 3-year contract was about 6 per cent less than for a 1-year contract. The largest companies had the highest prices. ${ }^{23}$ This situation is perhaps typical of a market recently opened to competition, where new entrants undercut incumbents and the latter are initially reluctant or not pressed to respond.

Table 6 Energy charges in Sweden (ore/kWh) with effect from 1 August 2003 (for household consumption 5,000 kWh/yr)

\begin{tabular}{llll}
\hline & Standard tariff & 1 year contract & 3 year contract \\
\hline Average & 47.11 & 37.77 & 35.53 \\
& & & \\
Vattenfall & 55.94 & 40.80 & 35.80 \\
Fortum & 55.80 & 40.66 & 38.66 \\
Sydkraft & 53.30 & 38.30 & 37.80 \\
Plusenergi & 41.54 & 39.80 & 39.50 \\
& & & \\
Telge Energi & 45.02 & 38.52 & 36.22 \\
Elbolaget i Norden & 47.88 & 38.40 & 35.30 \\
Malarenergi & 40.40 & 36.60 & 34.60 \\
Skelleftea Kraft & 41.00 & 35.12 & 31.82 \\
\hline
\end{tabular}

Source: montel powernews, week 24, 2003

However, the situation has since changed. The largest companies began to cut their retail prices (while nonetheless increasing their generation margins). This change in policy reflected a response to emerging retail competition and also to customer dissatisfaction with their high prices, poor customer service (including several weeks of outages after big storms), high profits and directors' bonuses. The quickest way to repair their reputation was to cut prices. By March 2005, the Big Three suppliers were ranked in the middle of the price range rather than at the top. ${ }^{24}$ At times they reportedly had the lowest prices in the market.

The market has proved remarkably thick, and the range of contracts seems to have been expanding. On 12 June 2005 the consumer website listed 392 offers from 71

\footnotetext{
${ }^{22}$ This same has been true of moving from an incumbent to a competing supplier versus moving between competing suppliers in the UK, and presumably in other markets too.

${ }^{23}$ The first four companies in Table 7 - the largest suppliers - had energy charges around 5 percent above the average. The last four suppliers in Table 3 - the smaller suppliers ranked $8^{\text {th }}$ to $12^{\text {th }}$ in the original table — had charges around 5 per cent lower than the average.

${ }^{24}$ They were listed between $17^{\text {th }}$ and $26^{\text {th }}$ out of 64 offers listed on the consumer website. Spot related or variable prices were a little lower than fixed price contracts. The time gap between the two sets of observations was 18 months, but prices may have changed sooner than that.
} 
suppliers. The range of prices was considerable. ${ }^{25}$ The most popular contracts were for 1,2 and 3 years - the website listed over 60 different offers for each. It had over 40 offers for spot price contracts (see Table 7). In addition, there were small numbers of offers for contracts of 3,6 and 18 months and of 4 and 5 years. These contracts are available to all sizes of households. Most involve monthly billing, but many suppliers are willing to offer less frequent billing if that is what customers prefer. ${ }^{26}$

Table 7 Number of contract offers in Swedish electricity market ${ }^{27}$, June 2005

\begin{tabular}{llll}
\hline $\begin{array}{l}\text { Type of } \\
\text { contract/Size of } \\
\text { customer } \\
\text { (kWh/year) }\end{array}$ & $20,000 \mathrm{kWh}$ & $5000 \mathrm{kWh}$ & $2000 \mathrm{kWh}$ \\
\hline $\begin{array}{l}\text { Spot } \\
3 \text { months }\end{array}$ & 48 & & \\
6 months & 5 & 44 & 42 \\
1 year & 71 & 8 & 9 \\
18 months & 2 & 5 & 5 \\
2 years & 67 & 69 & 69 \\
3 years & 68 & 2 & 2 \\
4 years & 5 & 66 & 66 \\
5 years & 4 & 67 & 67 \\
\hline
\end{tabular}

There is also variety over time, depending on the season, the pattern of Nordpool prices and customer sentiment. Typically a supplier will see an opportunity to match a perceived customer preference against a favourable wholesale situation, sign up a wholesale contract in order to make a retail offer against it, and close the offer when the number of retail customers matches the wholesale contract. This offer might be open for only a few weeks.

The following two case studies summarise the experiences and policies of a relatively small but very active competitor Telge Energi and the largest incumbent company Vattenfall.

\subsection{The origin of residential electricity contracts in Sweden: Telge Energi (TE)}

Contracts and spot price terms in Sweden originated with Telge Energi (TE), the electricity company from Sodertaljie, a municipality just outside Stockholm. The municipalities of Sodertaljie and Nykvarn jointly own the company. TE was the first competitor in the field and is now the most active residential supplier outside of the Big Three suppliers.

\footnotetext{
${ }^{25}$ The lowest offer was 71.4 ore/kWh, for a 3-month contract available to all types of customer. The highest offer ranged from 83.1 ore/kWh for a $20,000 \mathrm{kWh} /$ year house with electric heating to 107.7 ore $/ \mathrm{kWh}$ for a $2000 \mathrm{kWh} /$ year apartment. (These figures are higher than in Table 6 and elsewhere because they are for the total price including network charges, whereas the other figures refer only to the energy component.) In March 2005 the margin on spot contracts seemed to be in the range 8.9 to 14.2 ore $/ \mathrm{kWh}$.

${ }^{26}$ For a 3 year contract for a 20,000 kWh house on 11 June 2005, there were 68 different offers including all billing possibilities. There were 63 offers for monthly billing, 60 for bi-monthly, 51 for quarterly, 7 for 4-monthly, 11 for bi-annually and 6 for annually. It appears that most suppliers offer considerable flexibility in billing.

${ }^{27}$ Source: www.konsumentverket.se at 11 June 2005, including all billing options.
} 


\subsubsection{First steps}

Initially, TE had only 1 per cent of the Swedish market and wished to expand in order to secure economies from greater size. Its strategy was to aim at households using electricity for domestic heating, just over a fifth of all households. Before the competitive market opened these consumers were accustomed to uncertain and generally rising electricity prices. TE perceived them as wanting both lower and more certain prices. Its initial contract offering was a response to this.

In May 1997 TE offered fixed-price fixed-term contracts to its own customers at no reduction in prices, and got a very good response. Then it made offers outside its own area, of a 2-3 year fixed price contract at a $20 \%$ price reduction. There was a very good response from customers: $20-30 \%$ of electric heating households in Stockholm signed up within the first six months. This encouraged TE to offer the same types of contract at lower prices in other areas.

Apart from the price difference, fixed-price fixed-term contracts had two advantages over the tariff terms offered by the incumbents. First, they were similar to contracts in the mortgage market, with which customers would be familiar. Second, before profiling was introduced, customers choosing competitive supply had to install hourly metering. TE was able to give away the meters for free, with the fixed-price fixedterm contract recovering the initial metering cost over a predictable period of time.

Other companies followed TE. The incumbent suppliers began to offer fixed-price contracts below their standard tariff price but about 2-3 ore/kWh above the level offered by TE. Many customers accepted fixed-price contracts with their own suppliers rather than switch supplier. This meant that they continued to get a single bill whereas if the distribution and supply companies were different they would get two bills. They also avoided the inconvenience of changing supplier with its possibility of misread, inaccurate or missed bills, which was then a problem.

\subsubsection{Spot price terms}

In March 1998, about ten months after it had offered fixed-price contracts in Stockholm, TE began to offer spot price terms (Nordpool spot price plus 2.9 ore $/ \mathrm{kWh}$ to cover its costs) as part of its offer to provide free meters. On this basis it initially required a minimum agreement period of 2 years in order to cover metering costs. TE saw spot price as a way of offering innovative new deals and good prices to customers. Customers had some concerns that incumbents were trying to lock them into long contracts at high prices at a time when spot prices were very low. Developments in the electricity market at this time also reflected the recent liberalisation of the home mortgage market, where customers were beginning to explore new choices of spot versus term rates.

Again, some other suppliers followed suit. In the event - as with mortgages relatively few customers accepted spot price terms. At that time they preferred fixed price contracts in the expectation that electricity prices would normally go up each year. 


\subsubsection{TE's evolving customer base}

IT systems initially constrained TE's ability to accommodate new customers to an increase of about 10,000 per year. New IT systems removed this constraint, and more recently it has been attracting around 20,000 new customers per year. Table 8 sets out the evolving nature of its customer base and the choices of its customers as regards terms of contract. It now has four times as many customers as when it started competing some eight years ago. Only 15 per cent of all its customers are now on standard tariff terms.

Table 8 Composition and development of Telge Energi's customers

\begin{tabular}{llll}
\hline Type of customer: & May 1997 & Spring 2003 & Winter 2004/5 \\
Customers within area & & & \\
- on Standard tariff & 45,000 & 30,000 & 25,000 \\
- on individual agreements & 0 & 15,000 & 15,000 \\
Customers outside area & & & \\
- on individual agreements & 0 & 95,000 & 130,000 \\
Total number of customers & 45,000 & 140,000 & 170,000
\end{tabular}

Terms chosen by customers on individual agreements:

Spot price terms

Spring 2003 Winter 2004/5

Fixed price 1-3 year contracts

$11,000 \quad 13,000$

Total individual agreements

$\frac{99,000}{110,000 \quad 132,000}$

The preferences of customers as to duration of contract vary over time. Initially, most chose the 1-year contract. However, following the very high spot prices during winter 2003, most customers chose the 3-year contract. Nordpool prices turned down during the last part of 2004, contract prices went down too, consumers began to expect that prices would continue to fall during the coming year, and there was increasing demand for short (6 months) contracts.

\subsubsection{TE's present policy}

TE's present policy is to be the best supplier for households rather than the cheapest. It uses its knowledge to purchase electricity on the best terms and to make new kinds of offers that are more attractive to customers without necessarily involving a lower price. TE was among the first to offer six month contracts when Nordpool prices began to fall; in fact, between October 2004 and March 2005 half its sales were for such contracts. As another example, TE noted that a fixed price contract always involved an extra cost but the risk of high spot prices was only significant in the winter. Accordingly, in 2004 it introduced a new type of contract called 50-50, involving a fixed price during the winter and spot price at other times.

TE either does not wish, or is not able, to offer all types of contract. For example, a few companies (including Fortum and Sydkraft) have offered 3 month contracts. TE reports no demand for such contracts from its customers, and the set up costs and billing times make such a short period less attractive. (Its shortest contract has been 5 months.) A few companies have offered 4- and 5-year contracts. TE finds it difficult to get contracts on Nordpool to back an offer for more than 3 years. 


\subsubsection{Marketing}

TE makes offers to customers through direct mailing in the areas of the Big Three companies. In regional areas it supports this with small TV commercials, though national advertising is too expensive. About 25 per cent of new customer agreements follow directly from such a mailing, about 35 per cent from internet contact, which may be a response to a mailing, and about 40 per cent from phone marketing. TE does not recommend particular products that it offers, but rather invites potential customers to ask others what they are doing. TE's website in fact indicates the proportions of its customers choosing each type of contract at any time. ${ }^{28}$

\subsubsection{Market context}

TE's policy is to continue to grow, and to challenge the larger incumbent companies. ${ }^{29}$ However, growth is difficult because it is not yet the custom in Sweden to choose electricity suppliers. There has been little new entry into retailing since recent margins have been low. The larger integrated companies are perceived to have been increasing their margins in generation and reducing them in retail. ${ }^{30}$ For TE, the small number of active competitors is a problem rather than an advantage.

TE does not wish to integrate backwards into generation. It has tried to encourage a more competitive Nordic market. To that end it was instrumental in forming a new organisation of Independent Electricity Sales Companies, presently with 10 members, to focus more explicitly on retail issues than the existing industry organisation Svensk Energi did.

\subsection{The largest Swedish electricity supplier: Vattenfall}

Vattenfall is 100 per cent state-owned, and the largest of the Big Three companies in the Swedish electricity market. It has nearly half the generation output in the country, a $13 \%$ share of the residential market under its own brand, and a much higher share with associates.

\subsubsection{Vattenfall's company strategy}

Vattenfall's business strategy has evolved over time. When the residential market first opened, it explored attracting new customers. It concluded that electricity was an immature market where households were not yet ready to choose or did not care sufficiently about their supplier and the possible cost savings. Its aim then became to keep its existing customers rather than to attract new ones. But during 2003 the increasing pressure of competition, and substantial media criticism of the high prices and poor service offered by the Big Three companies, led it to reassess this strategy.

\footnotetext{
${ }^{28}$ For example, on 10 June 2005 TE's website (www.telgeenergi.se) reported that $43 \%$ of customers were choosing a spot price contract, $12 \%$ a 6 month contract, $29 \%$ a 1 year contract and $8 \%$ a 2 year contract. The remaining $8 \%$ of customers were presumably choosing some other type of contract.

${ }^{29}$ In 2004 TE ran a commercial with the slogan "Beware of the electricity giants". Its website contrasts its own relatively high quality standards with those of the larger companies.

${ }^{30}$ For example, it has been suggested that Vattenfall's generation margin increased from 10 to 14 ore/kWh while its retail margin fell from 0.8 to $0.5 \mathrm{ore} / \mathrm{kWh}$, and similarly for Fortum.
} 
In early 2004 it decided actively to seek new customers, to position its prices so as to achieve this and to avoid negative headlines, and to improve its quality of service.

\subsubsection{Vattenfall's pricing decisions}

Before the residential market was opened to competition, Vattenfall changed its standard tariff about once a year, an important decision taken just below Board level. With increasing competition, it became necessary to change the tariff price more frequently and to take this decision at a lower level. Since deregulation in 1999 Vattenfall has changed its standard tariff 13 times, an average of twice a year. It changed the tariff four times in the year to March $2005 .^{31}$

From 1999 to 2004 Vattenfall's pricing decisions were taken with a view to maintaining the retail margin; the decisions took into account recent and predicted Nordpool prices for the next 2-3 months, customer movements between suppliers, competitive price levels, and predicted reactions of customer numbers to price changes. During this period Vattenfall had one of the highest prices in the industry. Other companies tended to look to Vattenfall as the price leader in terms of content and timing. They also studied how Vattenfall set its contract prices. ${ }^{32}$

In Spring 2004 Vattenfall changed its pricing strategy, to take greater account of customers' concerns and competitors' prices. In 2004-5 it was generally in the low- to mid-price range for all products. The other Big Three suppliers Sydkraft and Fortum are perceived to have changed strategy too. In consequence, their main competitor TE is no longer perceived as having much lower prices overall. TE tends to focus on one product at a time and tries to be the cheapest supplier for that specific product, but the Big Three are more often than not cheaper than TE on other products. The price spread between the Big Three and TE can now sometimes be less than 1 per cent of the electricity cost (excluding grid charges and tax) for electrically heated houses, or less than half a per cent of the total electricity bill. ${ }^{33}$

\subsubsection{Standard tariff versus contracts}

Initially, the company faced a dilemma regarding tariffs versus contracts. On the one hand, many existing customers accepted the Standard tariff, which was profitable for the company. On the other hand, the company promoted the concept of contracts, and

\footnotetext{
${ }^{31}$ This was facilitated by a change in regulations that enabled incumbent suppliers to advertise tariff changes in local papers instead of having to give customers notice by mail. This significantly reduces the company's cost of making tariff changes.

32 There is a significant volume risk as well as price risk in this market, since customers may use more or less energy than forecast or than average. Vattenfall considers that it has good competence here whereas some other energy companies did not have. In winter 2002/3 several small companies had problems and a few went bankrupt because they had not properly calculated their volume risks.

${ }^{33}$ On 7 March 2005 these four companies were ranked between $17^{\text {th }}$ and $26^{\text {th }}$ out of 64 listed offers for a 1 year contract; the spread between their offers was about $1.1 \%$ of the electricity cost excluding energy tax and grid charges (about $0.7 \%$ of the electricity price including energy tax but excluding grid charges). By 10 June 2005 they were ranked $13^{\text {th }}$ to $39^{\text {th }}$ out of 68 offers, and the spread had risen to about $2 \%$ of electricity price including energy tax but excluding grid charges. Of the four companies' offers, TE's was the second highest on 7 March and the highest on 10 June.
} 
wanted its customers to be active and to make a choice of preferred contract, which it considered would increase customer satisfaction. ${ }^{34}$

In the first few years Vattenfall took a rather passive line. The proportion of its customers on tariff prices was comparable to the national average, which was around 70 per cent in 2000 and 2001 and gradually falling thereafter. In late 2003, however, Vattenfall decided to reduce its tariff group as much and as soon as possible; it committed publicly to eliminating the tariff in due course. Whereas the national average in March 2005 was down to about 50 per cent tariff customers (see Table 3 above), Vattenfall's proportion of tariff customers was down to about 28 per cent, with a corresponding increase to over 70 per cent in the proportion of its customers on contract. $^{35}$

\subsubsection{Marketing and innovation at Vattenfall}

Vattenfall began to reorient its approach in 2002, with its project "Number One for the Customer" whereby "a fresh approach to our customers means electricity consumption on the customer's terms". This included offering new electricity price products in stages during 2003. One of these products launched in autumn 2003 was the 'Convenient electricity price'. This proved very popular with customers but was eventually withdrawn. ${ }^{36}$

Another new product is the Right to Change contract. A customer on a 3-year fixed price contract may purchase the right to change at any time to the present price for a 3 -year contract. This is potentially attractive in a volatile market where market prices may turn down after the initial contract is signed. This product is normally priced at between 70 and 600 kronor per year, depending on present and expected Pool prices and the customer's consumption. Vattenfall is the only company offering this option at present. It proved of interest to customers when 3-year contracts were popular in mid-2003 since it gave customers an option to lower their energy costs if prices went down without having to choose the volatile spot price.

As part of its policy to position itself more competitively, Vattenfall's purchasing strategy is now more closely tailored to its potential contract sales. ${ }^{37}$ It has begun to

\footnotetext{
${ }^{34}$ It cites survey evidence that customers who choose new suppliers are more satisfied than those who stay with old and existing ones, and that active customers are happier than passive ones. The company concluded that customers would stay longer if it let them decide the terms of their contracts, rather than just accepting what the company decided.

${ }^{35}$ Switching many tens of thousands of tariff customers per year to a fixed price contract is a substantial logistical exercise. There may be an irreducible minimum of tariff customers insofar as all customers who move into a new area - about 10 per cent of the total per year - get the tariff price automatically until they choose an alternative.

${ }^{36}$ This product guaranteed customers electricity for a given price per month independent of usage (like Powergen's Staywarm product in the UK). Several thousand customers signed up for it in the limited time that it was available. However, there were objections that it gave no incentive to save energy, even though it was targeted specifically at small consumers who could only save electricity by turning off lights or the refrigerator. In addition, there was a regulatory concern that low-volume customers would have to pay for high-volume customers, even though it was offered in three price-volume ranges and only for below- $5000 \mathrm{kWh} /$ year customers. Despite the popularity of the product with customers, the company decided that it could not survive the public debate.

${ }^{37}$ For the residential sector, Vattenfall's practice is to buy electricity in advance on the basis of a sales forecast for a specified number of customers. It then offers a fixed price contract for about two weeks
} 
offer rebates and special promotions in some cases. ${ }^{38}$ It is also reviewing its marketing strategy, which has hitherto focused mainly on telemarketing.

\subsubsection{Spot price contracts}

Vattenfall offers a spot price contract with a small fixed margin that is revised from time to time. Initially, the company did not actively promote this product because spot price is volatile and therefore not necessarily suitable for most domestic customers. ${ }^{39}$ It was also difficult to discuss 'risks' with customers, and the company did not want to focus on the negative aspects of deregulation at that stage. Only a very small proportion of its customers chose a spot price contract. Vattenfall continued to offer the product because its philosophy is to be a full service company and to meet all customer needs in an efficient way. If Nordpool prices had been less volatile, the company would have promoted spot price more.

In the event, the proportion of Vattenfall's customers on spot price has now increased to about 12 per cent of all customers, which is somewhat above the national average of 4 per cent (Table 5b above). Vattenfall is also one of only two suppliers in Sweden to introduce a capped spot price product. This provides that, in return for a fixed annual (insurance) premium, the customer pays the spot price up to a certain predetermined level, and the cap price if the spot price exceeds that level.

\subsubsection{Quality of service}

Vattenfall has been concerned to avoid bad publicity following substantial media criticism for high prices and poor quality of service. Its own surveys show that its customers think it has improved now. It has established its own customer service index, which stood at 58 in the past and by early 2005 was up to 63 . This is still not enough, and the company aims to improve still further over the next few years.

To this end, Vattenfall's retail and service outlets now have the longest opening hours and shortest queue times in the sector. It has also introduced some new customer service assurances, such as its 'switch supplier guarantee', whereby if Vattenfall delays a customer transfer on its own grid it will pay 300 kronor compensation (about US\$40). It has also introduced its 'one year guarantee' never to charge any customer for any unbilled consumption beyond one year regardless of whose fault it was.

Some UK companies have introduced new IT systems to overcome inflexibilities in their legacy systems. In contrast, Vattenfall has found that its old systems were too flexible, leading to many data quality errors that were expensive to correct. It is in the

\footnotetext{
at a time. It has a weekly check on its forecasts, and reviews its prices and products twice a month. The required two week 'cooling off' period at first seemed to present a problem, since "two weeks is an eternity in hedging terms". (Indicative offers to larger customers may be held open for only a matter of minutes.) In practice, however, few residential customers invoke the cooling-off provision.

${ }^{38}$ These promotions have included waiving the fixed annual cost on a contract, rebating the $\mathrm{kWh}$ price, a discount on telecommunications products, and free access to other products for which a fee is normally charged, such as the Right to Change contract.

${ }^{39}$ Household customers, especially those with electric central heating, are very vulnerable to spot prices. The average annual consumption per household is $7-8000 \mathrm{kWh}$, more than twice that in the UK, and there is greater vulnerability to climatic (hydro) conditions.
} 
middle of introducing a new billing system intended to simplify the billing process and reduce its costs.

\section{THE RETAIL ELECTRICITY MARKET IN NORWAY}

Norway is a smaller market than Sweden, and characterised by greater dominance by a state-owned company. Nevertheless, there is a remarkably active retail market, particularly with respect to spot price-related contracts.

\subsection{Market shares in Norway}

On the face of it, the Norwegian generation market is moderately concentrated. Statkraft presently accounts for 29 per cent of the generation market, the largest three generators for 41 per cent and the largest six for 58 per cent. ${ }^{40}$ However, there is a remarkable degree of cross-ownership between Statkraft and other large generators. Companies associated in some way with Statkraft or its owner the Norwegian state account for about half the generation market. The largest three independent groups of generators seem to have about 57 per cent of the market, and the largest six about 60 per cent.

At the retail level, there appears to be active competition for residential customers, although concentration among suppliers has increased. From 1997 to 2003 the three largest suppliers increased their total market share from 37.2 to 56.2 per cent, ${ }^{41}$ presumably mostly from merger rather than customers switching supplier. Even so, the residential sector is much less concentrated than the UK.

\subsection{Switching rate in Norway}

The number of residential customers with suppliers other than their local incumbent has steadily increased over time. In the largest 27 grid areas the proportion of household consumers with another supplier has increased from 5 per cent in 1999 to 23.5 per cent at end 2004. The proportion varies across Norway: in many grid areas the proportion is under 10 percent but in two areas it is over 50 per cent.

Moreover, the rate of switching per quarter has also increased over time, at least until mid-2004. The switching rate seems to be related to tariff increases: it reached a peak in winter 2002/3 when standard tariff rates increased sharply, reflecting the Nordpool price spike. There were smaller peaks in switching in the previous two winters, when prices tended to be higher.

In most grid areas more than 30 suppliers are active, and in some areas up to 100 suppliers are. This is not to say that all these suppliers secure a large market share. In 2004, NVE identified the top 5 suppliers in each of the main grid areas. They

\footnotetext{
${ }^{40}$ Personal communication, NVE, 17 June 2005. The shares of the largest companies seem to have been declining recently. In 2001, Statkraft had 37 per cent of the generation market, and a large number of other generators had up to 8 per cent each. The largest three generators had about 53 per cent of the market and the largest six about 72 per cent. A Powerful Competition Policy, Report from the Nordic competition authorities, Copenhagen, Oslo, Stockholm, 20 June 2003, section 3.4.1, pp. 48-50.

${ }^{41}$ This and much following information from The Norwegian End-User Market, Lars Olav Fosse, Advisor, Office of Electricity Market, NVE, slide presentation March 2005 and subsequent discussion.
} 
accounted for about 94 per cent of the customers in each area. The aggregate market share of the remaining suppliers in each area averaged only around 6 per cent.

Of the 130 suppliers to households, about 30 are considered to compete nationally. In fact, the NVE exercise just mentioned seemed to identify three main types of supplier. 25 suppliers were in the top 5 in only one area, presumably their own area, and did not compete effectively elsewhere. 11 suppliers were in the top 5 in 2 to 5 areas, presumably including their own, so evidently competed quite actively in 1 to 4 other areas, perhaps locally. Finally, 4 suppliers were in the top 5 in 11 or more areas these seem to be the truly national and effective competitors. It thus seems that about 15 suppliers constitute the main competition to the incumbent suppliers. But even this seems a relatively healthy number compared to some other markets.

\subsection{Tariffs, contracts and spot prices in Norway}

Traditionally, incumbent suppliers set a standard variable tariff to the customers in their area, which could be changed at relatively short notice (now 14 days). Over time, a variety of alternative terms has been offered. The proportions of households choosing each alternative has fluctuated over time but has generally increased. Figure 2 shows that about 20 per cent of Norwegian households are now on fixed price contracts. $^{42}$ No less than 15.9 per cent are on electricity contracts tied directly to spot price. There are several variants of these, including optional caps on the maximum price payable at any time. ${ }^{43}$ The proportion of Norwegian households on standard variable tariffs is now down to 64.7 per cent. ${ }^{44}$

In Norway, residential competition reportedly started with competitors offering a 'floating rate' directly related to the spot price, whereas in Sweden the first competitive offering was a fixed price. There is speculation why the percentage of customers choosing spot price contracts should be higher in Norway (now about 16\%) than in Sweden (now about 4\%). It is said that Swedes are more risk-averse by temperament and tend to choose fixed interest loans, whereas Norwegians dislike paying a risk premium for fixed price contracts and prefer floating rates - for example, for mortgages. It is also said that, historically, Norway has been more exposed to Pool price variations because of its greater dependence on the weather for availability of hydro-electricity, hence there is a greater tolerance of electricity price fluctuations there. ${ }^{45}$

\footnotetext{
${ }^{42} 10.7$ per cent are on 1-year contracts and 8.7 per cent on other fixed price contracts, thought to be mainly 3 -year contracts.

${ }^{43}$ There is no standard prescribed way of calculating spot-related tariffs, so at times it has been profitable to switch from one spot-related tariff to another, depending on movements in Pool prices. ${ }^{44}$ Statistics Norway, Table 3 Range of electricity prices in end-user market and distribution of sold quantity in the sample. http://www.ssb.no/en/elkraftpris/. These data are based on returns from a sample of 55 electricity suppliers for one week in the middle of each quarter, covering about 16 per cent of the suppliers and 60 per cent of the quantity supplied.

${ }^{45}$ As noted earlier, the dominance of hydro electricity in Norway means that there are bigger swings in availability and price on a seasonal basis than in a more balanced system such as Sweden or a predominantly thermal system such as the UK. By the same token there is less variability on an hourly basis because all hydro plants have about the same (opportunity) cost in each hour. Some suggest that this range of variability makes spot price contracts more acceptable in Norway, less acceptable in Sweden, and not at all in the UK.
} 


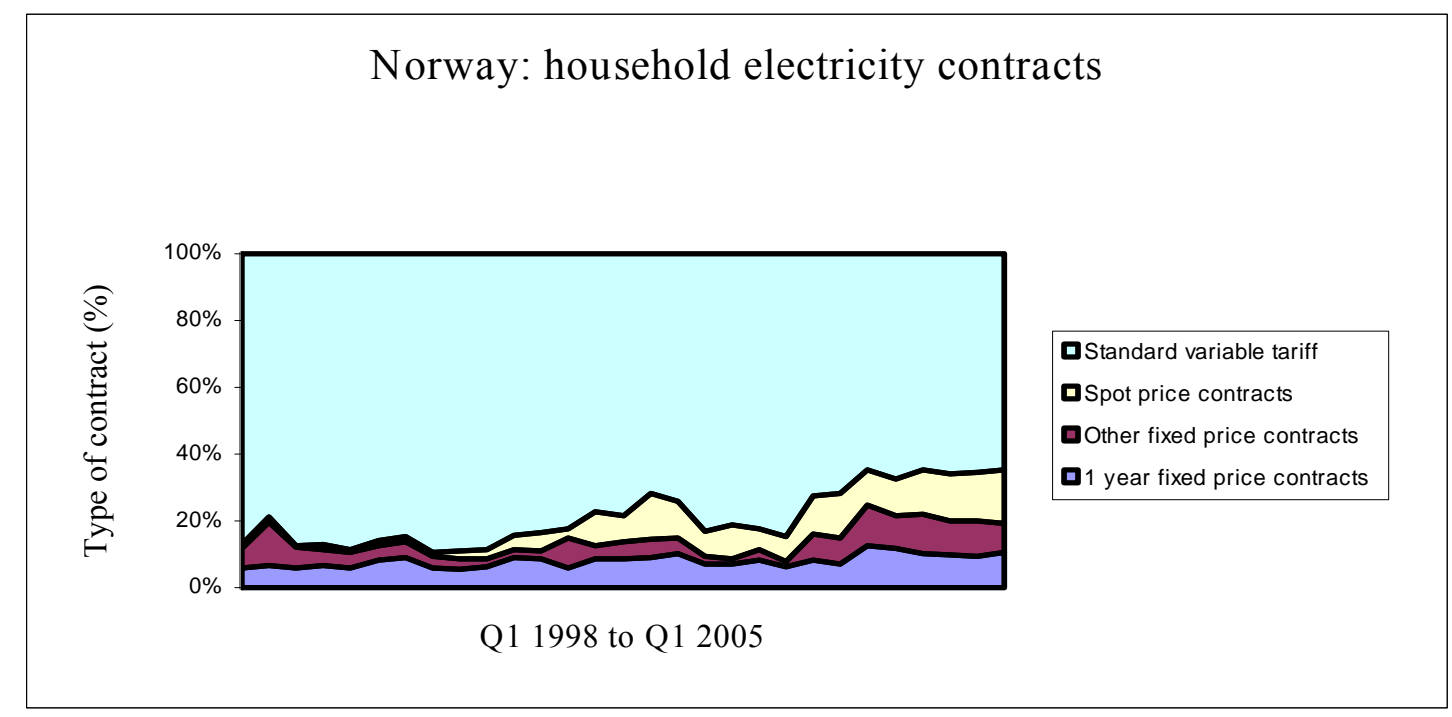

Source: Statistics Norway

Another factor seems to be that the standard variable tariffs in Norway have become so variable, and so linked to movements in spot price albeit with a lag, that the concept of explicit spot price contracts is not as novel as it appears in Sweden. For example, whereas Vattenfall in Sweden has changed its tariffs twice a year since 1999 (section 2.4.2 above), the main suppliers in Norway have been changing their variable tariffs at least once a month on average since 2001, to reflect changes in pool price. ${ }^{46}$

The standard variable tariff has thus become a means of competing in Norway, or at least this tariff has to respond to competitive offers. Figure 3 shows that prices of variable tariffs and the various forms of contract now seem to move broadly together, in line with spot price. Variable tariffs tend to be a little above the price of spot price contracts, and were notably so in the exceptional winter of 2002/3. For the first few years after the residential market was opened, fixed price contracts were generally more expensive than both these options. That is, customers paid a premium for certainty, and a higher premium for 3 years' certainty rather than 1 year. ${ }^{47}$ Since the winter of 2002/3, however, fixed price contracts have often been less expensive than variable tariffs and spot price contracts, and 3 year contracts have been less expensive than 1 year contracts. The observations for part of 2004 and especially for first quarter 2005 suggest that the earlier relationship may now be re-establishing itself. ${ }^{48}$

\subsection{Relative prices by different suppliers in Norway}

There are some concerns that competition is not yet fully effective in Norway. Table 9 shows that in 2004 the cheapest suppliers were on average about 3 per cent lower than

\footnotetext{
${ }^{46}$ On average, the dominant suppliers in the largest grid areas changed their prices in 27.8 per cent of weeks between week 272001 and week 48 2003, and 27.3 per cent of weeks between week 12004 and week 12 2005. Lars Olav Fosse, NVE, communication of 9 March 2005.

${ }^{47}$ This is the opposite of the case in Sweden (see above) where fixed price contracts were initially offered at a lower price than the variable tariffs.

${ }^{48}$ Note also that Table 9 below suggests that in 2004 variable tariffs were at a premium of about 3 to 6 per cent above spot price terms, and one year contracts about 4 to 5 per cent above variable tariffs.
} 
the largest household suppliers on spot-price related terms and about 7 per cent lower on variable tariffs and one year contracts. ${ }^{49}$ Whether these various differences are a sign of competition or the lack of it is perhaps debateable, but they at least do seem to indicate a competitive process in action.

Table 9 Electricity costs per year for $20,000 \mathrm{kWh} /$ year household in Norway

\begin{tabular}{|l|l|l|l|l|}
\hline Type of supplier & \multicolumn{2}{|l|}{ Average 5 largest suppliers } & \multicolumn{2}{l|}{ Average 5 cheapest suppliers } \\
\hline Type of terms & Ore/year & Normalised & Ore/year & Normalised \\
\hline $\begin{array}{l}\text { Standard } \\
\text { variable tariff }\end{array}$ & 7052 & 109.4 & 6639 & 103.0 \\
\hline $\begin{array}{l}1 \text { year fixed } \\
\text { price contract }\end{array}$ & 7375 & 114.4 & 6895 & 106.9 \\
\hline $\begin{array}{l}\text { Spot price with } \\
\text { mark-up }\end{array}$ & 6651 & 103.2 & 6447 & 100.0 \\
\hline
\end{tabular}

Source: Fosse, Norwegian End-User Market. Largest suppliers: Hafslund ASA, Fjordkraft AS, LOS AS, Lyse AS and Eidsevia Energi Marked AS. Cheapest suppliers: the 5 nation-wide suppliers with lowest average price on standard variable tariffs in 2004. All terms refer to major grid areas.

Figure 3 Household electricity prices in Norway 1998-2005, by contract type

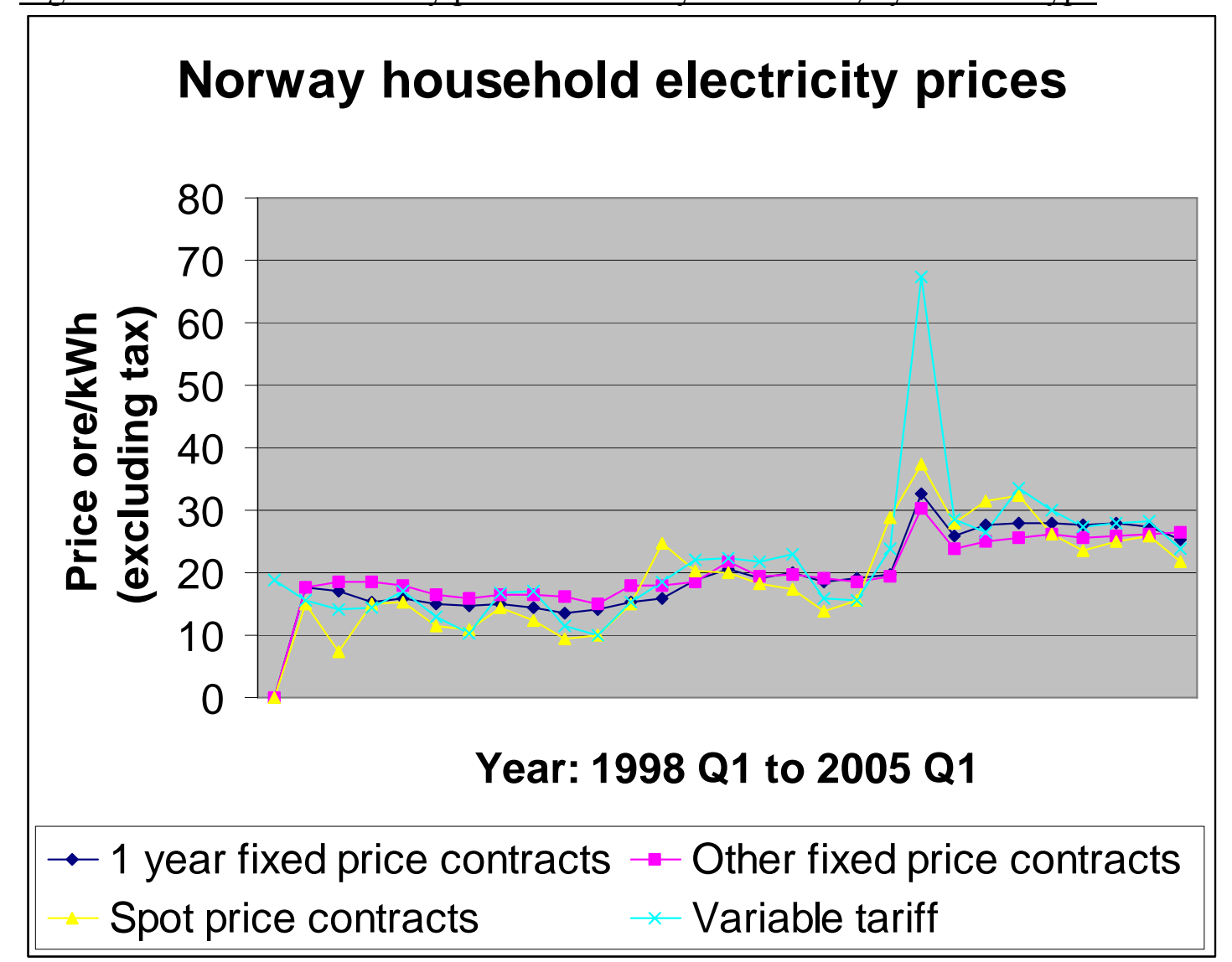

Source: Statistics Norway

\footnotetext{
${ }^{49}$ There were naturally variations within each group. Among the 5 cheapest suppliers, the lowest price was 1 to 2 per cent lower than the average on all three types of contract. Among the 5 largest suppliers, the highest price was about 2 per cent higher than the average on spot price terms, but some 7 to 8 per cent higher than the average on variable tariffs and 1 year contracts.
} 


\section{THE RETAIL ELECTRICITY MARKET IN FINLAND}

\subsection{Background and market structure in Finland}

Retail competition has not yet developed as much in Finland as in Sweden or even Norway, and there have been concerns about the strength of competition there. ${ }^{50}$ Nonetheless there are some interesting and promising developments. ${ }^{51}$

The Finnish electricity sector is diverse, with 91 distribution grid operators (about $20 \%$ municipal, $30 \%$ private, $50 \%$ mixed) and about 70 retail suppliers. The latter are mostly associated with distribution operators and tend to focus on the customers in their own regional areas. As yet, the market is very disaggregated. As from 1 January 2007, the most strict legal separation of supply and distribution businesses is required for companies with more than 100,000 customers (about 3 per cent of the market), but only six grid operators meet this condition. ${ }^{52}$

Incumbent suppliers are required to set Standard Variable Tariffs ('list prices') for customers in their areas. The restrictions on changes in standard tariff prices are more severe in Finland than in Norway and Sweden. ${ }^{53}$ However, all suppliers are allowed to offer any price to any customer (in their own area or elsewhere), and on request are also allowed to match the price offered by any competitor.

The top three suppliers have about one third of the total retail market between them, net of the usage of the largest industrial users (forestry) that buy direct from the wholesale market. Of the 70 retailers, about 50 are now willing to offer terms outside their own area.

\subsection{Concerns about the slow growth of retail competition in Finland}

The proportion of residential customers switching supplier has been low, around 5 per cent in 2001/2. This has been a matter of comment. In partial explanation, the switching process is a more restrictive than in Sweden and Norway. ${ }^{54}$ But it seems

\footnotetext{
${ }^{50}$ E.g. Lewis et al 2004.

${ }^{51}$ Sources: Annual Report of Energy Market Authority (henceforth EMV) 2003, 2004; The Finnish Retail Electricity Market, slide presentation Antti Paananen, EMV, 8 March 2005; Lewis et al 2004.

52 These 6 grid operators account for $49 \%$ of the customers. There are increasingly less onerous conditions for 50,000 - 100,000 customers ( 9 operators, $22 \%$ of customers), under 50,000 customers but demand over $200 \mathrm{GWh} /$ year (17 operators, 16\% of customers) and demand under $200 \mathrm{GWh} /$ year (59 operators, $16 \%$ of customers). The relevant amendment to the Electricity Market Act came into force on December 27th, 2004. Source: EMV.

53 "Norwegian and Swedish suppliers can change their [tariff] prices with just two weeks notice whereas in Finland the minimum notice period is four weeks. In Finland, suppliers need to inform customers in person (through letter or customer magazine etc.), whereas in Norway and Sweden even notices in newspapers are normally sufficient. [In Norway, customers must be informed directly if the price change is more than 2.5 ore $/ \mathrm{kWh}$ (approximately $10 \%$ of a typical residential electricity bill, power only).]" Lewis et al 2004, p. 99.

54 "In Norway, customers can effectively switch supplier (without extra meter reading fees) as often as they wish [fn: in which case they need to self-read and report their meter level] and the switching process must not take any longer than three weeks. In Sweden, customers can also switch away from an incumbent supplier (without extra meter reading fees) whenever they wish (but can only change to a fixed-term or spot price tariff) and the process of switching should take not more than one month. In Finland, customers can only switch once per year (without extra meter reading fees) [fn: in Sweden and Finland customers can switch supplier (without extra metering fees) if their incumbent electricity
} 
unlikely that this would significantly restrict the number of first-time switchers. More general concerns about the extent of competitiveness in the Finnish retail electricity market have been the apparent lack of sustained interest in competing on the part of retailers themselves, and the apparently limited relationship between wholesale and retail prices.

When the residential market opened in 1998, many suppliers introduced a price cut of around 15 per cent to their own customers, so there was less headroom for competitive suppliers. Incumbent suppliers have reportedly been willing to match competitors' offers to their customers rather than see them leave. ${ }^{55}$ Pool prices then increased but list prices lagged behind. In early 2004 it was estimated that retail sales had been loss-making for several years. ${ }^{56}$ In response to the low prospective return, and the low switching rates, retailers cut back on their marketing activities. Some suggest they largely abandoned retail competition. ${ }^{57}$

Figure 4 shows that list prices have traditionally been rather stable, and unresponsive to NordPool price. Many suppliers have their own generation plant (distribution utilities account for some 20 per cent of generation) and are therefore less dependent on Pool prices than pure retailers. The municipalities are said to like a stable income. When the Pool price shot up in winter 2002/3, list prices lagged behind Pool prices, and for a time contract offer prices exceeded list prices. Many retailers were unwilling to make offers beyond their statutory obligations to customers within their areas.

Figure 4 List prices, offer prices and spot prices in Finland

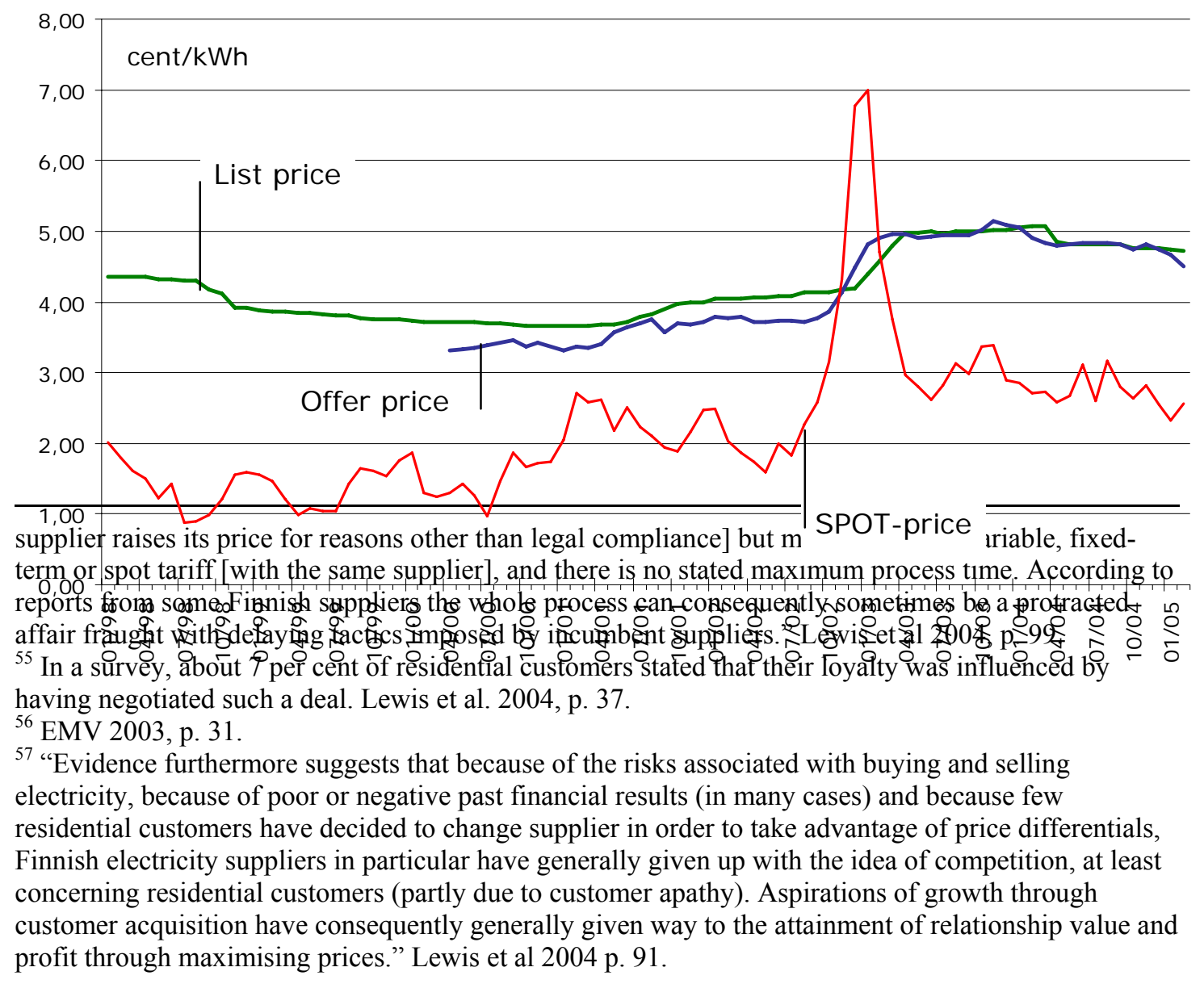


Subsequently, list prices increased and Pool prices declined. Recently, list prices have fallen slightly, but some question whether they have fallen sufficiently to match the Pool price decline. ${ }^{58}$

\subsection{Recent developments in Finland}

If indeed retail sales were loss-making, then it is understandable if retailers were losing interest in competing, and that a higher margin is now establishing itself. This should rekindle interest in competition, and indeed there seems to be some evidence of this. It is reported that suppliers have become more advanced with their risk management and pricing. ${ }^{59}$ Figure 4 suggests that there is now a closer relationship between list prices, contract prices and Pool price. The next two case studies suggest that different kinds of suppliers are increasingly interested and prepared to compete, and are now offering a variety of different contract forms. These are evidently of growing appeal to customers, and perhaps 20 per cent of customers have now chosen contracts of one to two years duration. ${ }^{60}$ The proportion of customers that have switched supplier increased to about 11 per cent in 2004.

There are no formal barriers to entry in Finland - for example, no licence is required for generation, trading or retail supply, so even a private individual could become a retail supplier. ${ }^{61}$ Some large foreign players (Vattenfall and E.On) have entered by acquiring existing Finnish businesses. There has been a small amount of completely new entry into retail. Housing and other associations have been active in affinity arrangements. Halpa Halli, a chain of department stores, started to sell electricity about three years ago. Station 1, owned by a group of gas stations, sells via the internet. Turku Energia is a particularly innovative and competitive city utility. These last two suppliers offer spot-related pricing to residential customers. ${ }^{62}$ The role of suppliers may also be evolving in the face of increasing market volatility. ${ }^{63}$

\footnotetext{
${ }^{58}$ Lewis et al 2004. There is also some concern about the lack of transparency of price matching and the varying tax and financial policies of the municipalities.

${ }^{59}$ Lewis et al 2004, p. 90.

60 "It is estimated that around 80 per cent of residential customers in Finland currently receive standard consumer prices from incumbent suppliers.” Lewis et al. 2004, p. 36. Contracts over 2 years are not allowed in Finland, and only a very few customers have chosen spot price terms.

${ }^{61}$ An entrant needs to make arrangements with the local distribution grid operator, which is responsible for metering and also for energy balancing in its own area. This does not seem to have been problematic.

${ }^{62}$ Spot pricing was introduced at an unfortunate time in Finland, just before the spot price shot up in winter 2002/3, but these suppliers evidently believe there is still some interest.

63 "Electricity suppliers are increasingly being seen and appreciated for being advisors and 'middle men' as opposed to sellers. Their skill and contacts in risk and portfolio management, as well as their overall expertise in energy and energy market issues, are apparently appreciated more and more by I\&C customers." Lewis et al 2004, p. 38.
} 


\subsection{The development of regulation in Finland}

There have been concerns about the availability of information and the limited role of regulation. ${ }^{64}$ The Energy Market Authority was active in a number of areas in 2003-4, notably with the introduction of emissions trading activities and the ex ante regulation of distribution charges. It has now expressed some concern about the slow

development of retail competition, and has taken various steps to facilitate the market. This includes explaining how to get a competitive quotation ${ }^{65}$ and providing a better website for customers to compare prices. ${ }^{66}$

\subsection{A large new entrant: Vattenfall in Finland}

Vattenfall established an office in Finland in 1994, bought its first Finnish companies in 1995 when the market was opening, and has acquired further companies over the period to 2000. It is now one of the four largest electricity companies in Finland (the others being Fortum, Helsinki Energy and E.On). Vattenfall has chosen to operate its distribution network and sales operations in Finland as separate companies, going beyond the present separations requirements. It now has 325,000 households (strictly, points of delivery) in its territory.

When the residential market opened in 1998, wholesale and Nordpool prices were falling to reflect favourable water supply, and there was the pressure of impending retail competition. Vattenfall lowered its tariff prices by about 20 per cent. It also launched what was then a new type of contract, with a fixed price for a fixed 2-year term, at a price about 10 per cent lower than the tariff price. It sent a personal offer to every existing Vattenfall customer (which caused some problems with backoffice work and customer telephone calls) and 30 per cent of its customers opted for the fixed term contract.

At the same time Vattenfall was active in marketing to new customers. However, customers were not very willing to change supplier, a new concept at that time. This meant that the cost of customer acquisition was high. TV and direct mail had a low hit

\footnotetext{
${ }^{64}$ Consumer price information websites in Finland are said to be less informative than those in Norway and Sweden. Moreover, "The Finnish regulator is clearly the least resourced regulator amongst the three [Nordic] markets. Regardless of its limited mandates, its ability to supervise activities in the electricity supply market is extremely limited regarding, for instance, market behaviour-tracking and customer behaviour." Lewis et al 2004, pp. 93-4, 99-100.

65 "In order to encourage consumers, the Energy Market Authority published a brochure on how to make electricity companies compete in autumn 2004. The Electricity Market Authority wants to correct the idea prevailing among consumers, according to which it is complicated and almost useless for the consumer to invite electricity tenders. The brochure 'Buy affordable electricity by inviting tenders' reveals how electricity tenders can be invited smoothly and swiftly in practice and how the tenders should be compared with each other." EMV Annual Report 2004, p. 14.

66 "There are price-related commercial services available on the market. Although they have helped to make the price data available to consumers, they have many significant defects. The prices are not always current prices, because only a few electricity retailers make their prices available to the service providers. In addition, some services are subject to a charge that either the consumer or the seller has to pay, and some services may be complicated to use or are not well-known and therefore have a small number of users. ... The situation requires the creation of an easy and uncomplicated system by which electricity users, especially household consumers, can reliably check the best electricity offers. ... The Electricity Market Authority is designing a system for its web site which will enable electricity users to obtain real-time information on prices swiftly from one place." EMV Annual Report 2004, p. 14.
} 
rate; telemarketing would have been more effective but also more expensive.

Vattenfall decided to build partnerships to attract new customers, including with the co-operative S-Group ${ }^{67}$, the Federation of Finnish Enterprises, the Federation of Finnish Farmers, etc. S-Group uses bonus cards yielding a discount on purchases (normally up to 5 per cent), which is now available on electricity too. Some of these partnerships were exclusive, others were not. In general partnerships proved most cost-effective as regards marketing and loyalty, and Vattenfall is foremost in this approach.

Vattenfall offers a variety of different price levels and discounts, as many as five in some cases. It is sometimes the most competitive on price but not always, particularly when Nordpool market prices are high. It buys on Nordpool and prices its products accordingly. Some other companies have their own generation, and price on the basis of their own costs rather than Nordpool prices. Some of these other companies are also able to absorb losses in other activities and act uncommercially, so that clear unbundling is important if the competitive market is to develop.

In the early days, the company encountered various problems with retail competition. Many suppliers were not ready for the competitive market. Processes for customer transfer were not yet well established, either by grid companies or by suppliers. Some existing suppliers and network operators resisted customer transfers (e.g. by levying an additional fee for meter reading or higher distribution charges on customers that changed supplier). Service levels in many companies were poor. But most of these problems are now largely resolved.

Vattenfall now offers fixed price 2 year contracts outside and within its area, plus a variable tariff within-area. In the future it sees only fixed term contracts, and not tariffs. Such contracts make it easier to purchase electricity, and contract customers are more loyal. At present only a small percentage of Vattenfall's customers are from outside its area, but nearly half of its customers are on contracts. It has not offered a 1 -year contract, since contract renewal is costly for company and customer. It is precluded by the regulations from offering a 3-year contract, but in any case does not wish to do so. It has considered offering spot price terms, but surveys show that residential customers are not interested to take the full spot price risk. In the event of high spot prices they might leave to sign a fixed price contract with another supplier. However, the company is ready to launch a spot-price product if market sentiment changes.

Over time, Vattenfall has made many changes within the organisation to facilitate its efficient operation. For example, it outsourced its network construction to Empower in 2001 and merged its network businesses into one company Vattenfall Verkko in 2002. It centralised all customer data within one system, and is implementing a new SAP system during 2005. It is working with other companies to send a single bill to customers. In 2005 it began large-scale installations of remote readable meters, using the same GSM technology as in mobile phones, and plans to change all its meters within $2 \frac{1}{2}$ years. It calculates that the savings on meter-reading costs will match the investment costs.

\footnotetext{
${ }^{67}$ S-Group is a co-operative store present in many businesses and the second largest entity in the daily consumer goods business.
} 


\subsection{A municipal incumbent: Helsinki Energy}

Helsinki Energy (HE) was one of the first electricity companies in Finland. It is now owned by the city of Helsinki. Unlike some other electricity companies, it actively prepared for market opening, and considered how it could compete most effectively. It concluded that simply defending its own customer base was inadequate and expensive, and that it should aim to sell its product outside of Helsinki.

Because of the low temperatures, district heating is important in Finland. The cogeneration system makes it simple to produce electricity as well as heat. Before 1995 any electricity surpluses were sold on the wholesale market, although the price was not attractive. HE's present co-generation system can provide about twice as much electricity as needed for all those customers in the city of Helsinki, and the surplus can now be sold on the market and to other end-users.

In order to engender trust on the part of its customers, HE's policy is not to sell electricity to new (outside) customers at a lower price than it sells to its own customers in Helsinki. Normally it does not sell to them at a higher price either, although in the exceptional winter 2002/3 it had to do so, to avoid raising prices to its own customers. Many retailers even stopped making offers to new customers.

HE was never subsidised and always made a profit. Before the market opened, it set its prices with a view to covering its power plant investment costs over a 20 year horizon. Calculating prices was relatively straightforward. Now this is more difficult, and plans may need to be changed from hour to hour. The costs of investment have to be recouped in periods when prices are high enough to allow this - that is, when demand is high in relation to the electricity capacity available - rather than on an even basis in each year. Cost-based pricing has been changed to market-based pricing driven by the NordPool spot and forwards markets.

The company is now reorganised into separate functions (network distribution, sales and production). The sales department is responsible for buying and selling on the electricity markets - two different processes - so as to be able to offer customers competitive price levels.

HE's philosophy is to provide transparent pricing for large customers, so that they can trust the company. In 2002 it introduced its Dynamic Electricity contract involving a combination of spot purchasing and Nordpool forwards contracts, in the light of various identified scenarios and risks. ${ }^{68}$

At the residential level, HE reduced its variable tariff by 29 per cent when the market opened in 1998, to establish good relations with its customers. Low wholesale market prices and HE's efficiency allowed it to keep its retail prices low and stable until 2001. Rising wholesale prices, particularly in winter 2002/3, necessitated some price increases, and improved purchasing efficiency by other companies has meant that

\footnotetext{
68 "Customers are more willing than before to sign electricity contracts of a long duration, and their need can be met, because the Dynamic Electricity contract makes it possible to fix the electricity price in stages for as many as three years after the signing of the contract." Annual Report 2003, Helsinki Energy, p. 6.
} 
HE's advantage has narrowed. Nonetheless, it has attracted new customers and lost quite few. It expects more switching in future.

Initially, HE concentrated on its variable tariff and (exceptionally among competitive suppliers) did not offer contracts. However, it now sees the market changing: there is greater uncertainty about wholesale prices and new costs to consider (such as CO2). It has concluded that customers will come to appreciate contracts, and it has therefore decided to make them available. HE will use hedging products to minimise the risks for households too (though not all risks can be offset, such as changing load profiles and abnormal temperatures). As it indicated last year, the intention was to offer 1- and 2-year contracts in Spring 2005 and those products are already available for HE's own customers.

\section{CONCLUSIONS}

The Nordic electricity markets are of particular interest with respect to the development of retail competition at residential level. In some ways the structure of the market is not promising. For example, a few vertically integrated players tend to dominate in each national market, but to some extent the ability to trade between these national markets offsets this. The municipal ownership of most distribution and retail entities may reduce their ability and incentive to compete for customers, but this is perhaps offset by the sheer quantity of players, the consequent thickness of the wholesale markets, and the greater likelihood that at least some of them will be willing and able to participate in the retail markets. Importantly, too, the extent of municipal and state ownership may explain the absence of price controls or other restrictions on the final retail price. This has enabled retail competition to flourish in the Nordic residential electricity markets, which has not be the case in all other such markets.

A significant proportion of residential customers - ranging from 11 to 29 per cent has switched away from incumbent suppliers. Of particular interest is the everincreasing richness of contractual forms emerging. Between 20 and 50 per cent of residential customers have actively turned away from the traditional tariff that is variable at the supplier's discretion. These customers have chosen either a fixed price contract for between 3 months and 5 years (mostly 1,2 or 3 years), or a spot-price contract directly related to the NordPool spot market price. Table 10 summarises the present situation.

Table 10 International comparison of residential contract types

\begin{tabular}{|l|l|l|l|l|}
\hline \hline Country & Sweden & Norway & Finland & UK \\
\hline Switched supplier (\%) & 29 & 24 & 11 & 42 \\
\hline & & & & \\
\hline Variable tariff (\%) & 50 & 65 & 80 & $>60$ \\
\hline Variable tariff with cap (\%) & 0 & 0 & 0 & 30 \\
\hline & & & & \\
\hline$\leq 1$-year fixed price contract (\%) & 19 & 11 & \multirow{2}{*}{20} & \multirow{2}{*}{$<10$} \\
\hline 2-year fixed price contract (\%) & 10 & \multirow{2}{*}{9} & & \\
\hline$\geq 3$-year fixed price contract (\%) & 17 & & 0 & 0 \\
\hline Spot-related contract (\%) & 4 & 16 & $\sim 0$ & \\
\hline
\end{tabular}




\begin{tabular}{|l|l|l|l|l|}
\hline & & & & \\
\hline Total (\%) & 100 & 100 & 100 & 100 \\
\hline
\end{tabular}

Source: present text for Nordic countries, Littlechild (2005b) for UK.

For comparison, the final column of Table 10 summarises experience in the UK. The proportion of switching is much higher there, at over 40 per cent, though it has not been increasing much recently. ${ }^{69}$ In contrast, the ' 28 day rule', which requires that all residential customers be able to change supplier at 28 days' notice, seems to have discouraged the provision of fixed-term contracts. In the last two years, following hitherto unusual price increases, the major suppliers have responded to customer concerns in two ways. Four suppliers have on a few occasions offered a fixed price for a fixed period in return for an additional charge. At any time at most one such option has been available from each company. This option is comparable to a contract offered in the Nordic countries except that customers are able to leave at 28 days' notice, sometimes with a cancellation fee. My estimate is that under 10 per cent of all residential customers have actively chosen one of these options. The other two major suppliers have promised not to increase their variable tariff price until January 2006, so that all their customers automatically have a temporary tariff cap without having chosen or paid for it. The combined residential market share of these two suppliers is presently about 30 per cent.

The Nordic markets thus have much greater variety of contract forms than the UK. In addition, a greater proportion of customers ( 20 to 50 per cent compared to under 10 per cent) has exercised choice in this respect.

Nordic experience suggests a number of conclusions. As regards consumer preferences, a) a significant proportion of residential customers prefer such contracts rather than the traditional variable tariff; b) the proportion of such customers has increased over time; c) at any one time these customers have different preferences one from another; and d) customers' preferences seem to evolve over time in response to experience. For example, some customers seem to assume that future spot prices will follow the pattern of recent past prices, and they choose long, short or spot contracts accordingly. Customers seem to honour these contracts: there is no suggestion that they renege on long-term contracts when market prices change.

As regards the behaviour of suppliers, a) suppliers differ significantly in their willingness and ability to compete in this way; $b$ ) this willingness and ability tends to increase over time; c) competition tends to be initiated by a few smaller players, who offer lower prices and/or innovations in contract form; d) larger dominant players are initially reluctant to respond, but over time have lowered their prices and also innovated, and become more professional and more competitive in their approach; e) the speed and nature of market response to spot market changes is also influenced by the ownership of market participants and the extent of vertical integration.

\footnotetext{
${ }^{69}$ The proportion of UK residential customers with another (non-incumbent) supplier increased steadily from zero in 1998 to about 40 per cent in 2003. In 2004 and early 2005 there was a strong burst of switching in response to hitherto unknown price increases, but the proportion of customers with nonincumbent suppliers increased to only 42 per cent by March 2005. In the 12 months to March 2005 $15 \%$ of customers changed supplier but only $2 \%$ net switched from incumbents to non-incumbents. (Ofgem, personal communication)
} 
There is obviously scope for more systematic economic and statistical analysis of these markets. It would be interesting to extend the analysis to costs and margins, and to make comparisons with competitive retail electricity markets in the UK and elsewhere, and also with other markets generally. Whether or not marketing costs and retail margins in the electricity sector are higher than they used to be, are they higher than observed in other comparable markets?

Nonetheless, some implications for policy can be drawn even at this stage. The Nordic markets have shown that 'retail competition works'. Competitive markets can indeed provide not only a variety of prices and a choice of supplier, but also a significant range of 'value-added services'. Comparison with other countries suggests that restrictions on prices and other terms of provision have tended to discourage or distort retail competition there. Importantly, this is not simply in terms of price and number of competitors: these more restricted markets seem to be characterised by less innovation and less variety of contracts and services than are the Nordic markets.

In some countries there has been resistance to opening residential electricity markets to competition. There have also been proposals to rely on price controls or other regulatory arrangements instead of competition. Such proposals have not acknowledged the wide range of decisions that then need to be taken by regulators instead of being left to customers and suppliers in the market.

For example, regulators are required to design a uniform product and impose it on all customers, to assess the future path of wholesale spot and forward contract prices, to indicate the appropriate purchasing and pricing policy for incumbent monopoly suppliers, to assess the various risks involved and to allocate them between producers, suppliers and customers. Proposals for regulation instead of retail competition have not explained why this would be sensible: why a uniform product is preferable to a variety of products, how regulators are to discover the most efficient patterns of wholesale purchasing and the preferences of customers at any time, and how they are to implement, monitor and continually revise this uniform product and associated purchasing policies as market conditions evolve.

Meanwhile, the Nordic markets have shown that retail competition works well. Residential customers and competing suppliers have proved quite capable of making their own mutually agreeable arrangements for purchasing and pricing power. At the same time they are agreeing how to share the inevitable risks of underlying movements in wholesale market prices. These arrangements are continually evolving and improving. Whether alternative regulatory arrangements can achieve this responsiveness, efficiency and flexibility remains to be demonstrated. 


\section{APPENDIX}

\section{A.1 Physical characteristics of the Nordic markets}

Table 11 sets out some physical characteristics of the three Nordic electricity markets, with data from the UK for comparison. The three countries vary between themselves in many respects, but have much in common compared to other countries. Thus Sweden has nearly twice the population of Norway or Finland, but all three countries are an order of magnitude less populated than the UK and many other European countries. Total electricity generation in each country is relatively high. Consumption per capita is between two and four times the UK level, which is about the average OECD level.

Average electricity consumption per household, which is about $4 \mathrm{MWh}$ per year in the UK, is double that level in Finland and Sweden, and four times that level in Norway. UK regulators take typical Low, Medium and High domestic consumption as using $1.65,3.3$ and $6.6 \mathrm{MWh} /$ year respectively. In the Nordic countries the benchmarks are 2, 5 and $20 \mathrm{MWh} /$ year, respectively. In the UK about one sixth of households have Economy 7 meters for overnight electric heating. In contrast, over 20 per cent of residential properties are electrically heated in Finland, over 30 per cent in Sweden, and most in Norway. ${ }^{70}$

Table 11 Physical characteristics of Nordic electricity markets

\begin{tabular}{|c|c|c|c|c|c|c|}
\hline Country & units & Norway & Sweden & Finland & Great Britain & source \\
\hline Population & m 2003 & 4.6 & 9.0 & 5.2 & 60.3 & STEM 2004 \\
\hline Electricity generation & TWh 2003 & 107 & 132 & 80 & 363 & STEM 2004 \\
\hline $\begin{array}{l}\text { Consumption per } \\
\text { capita }\end{array}$ & $\begin{array}{l}\mathrm{MWh} / \mathrm{yr} \\
2004\end{array}$ & 26.4 & 16.2 & 16.6 & 6.3 & IEA Dec 2004 \\
\hline $\begin{array}{l}\text { Household } \\
\text { consumption }\end{array}$ & TWh 2003 & 31 & $37 ?$ & 18 & 112 & $\begin{array}{l}\text { Lewis et al } 2004 \\
\text { Ofgem } 78 / 04 \text { p. } 7\end{array}$ \\
\hline Number households & $\mathrm{m}$ & 2.2 & 4.6 & 2.8 & 26 & \\
\hline $\begin{array}{l}\text { Average consumption } \\
\text { per household }\end{array}$ & $\mathrm{MWh} / \mathrm{yr}$ & 16 & 8 & 7 & 4 & \\
\hline Typical apartment & $\mathrm{MWh} / \mathrm{yr}$ & 2 & 2 & 2 & 1.65 & \\
\hline Typical house & $\mathrm{MWh} / \mathrm{yr}$ & 5 & 5 & 5 & 3.3 & \\
\hline $\begin{array}{l}\text { Typical house with } \\
\text { electric heating }\end{array}$ & $\mathrm{MWh} / \mathrm{yr}$ & 20 & 20 & 20 & 6.6 & \\
\hline
\end{tabular}

\section{A.2 Generation characteristics of the Nordic markets}

Table 12 shows that the individual Nordic wholesale generation markets are relatively concentrated. The figures are indicative rather than precise, but the largest generator in each market seems to account for about 40 to 50 per cent of total output (taking account of cross-ownership holdings), compared to around 20 per cent in the UK. The top three generators account for up 60 per cent, compared to about 40 per cent in the UK. In all four countries a rump of smaller generators accounts for nearly a third of the market.

\footnotetext{
${ }^{70}$ Lewis et al 2004, p. 76.
} 
$\underline{\text { Table } 12 \text { Generation characteristics of Nordic markets }}$

\begin{tabular}{|c|c|c|c|c|c|c|}
\hline Country & units & Norway & Sweden & Finland & $\begin{array}{l}\text { Great } \\
\text { Britain }\end{array}$ & source \\
\hline \multicolumn{7}{|c|}{ Generation market shares (approximate) } \\
\hline Largest 1 & $\%$ & $45-50$ & $45-50$ & $<40$ & 20 & STEM 2004 \\
\hline Largest 3 & $\%$ & $55-60$ & $55-60$ & $45-50$ & 40 & \\
\hline Largest 6 & $\%$ & 60 & 60 & $>60$ & 60 & \\
\hline $\begin{array}{l}\text { Hydro share of } \\
\text { generation }\end{array}$ & $\% 2003$ & $99-100$ & $40-50$ & $12-25$ & $0-1$ & $\begin{array}{r}\text { STEM } 2004 \\
\text { Lewis et al } 2004\end{array}$ \\
\hline $\begin{array}{l}\text { Imports share of } \\
\text { generation }\end{array}$ & $\% 2003$ & 7 & 10 & 6 & 3 & STEM 2004 \\
\hline $\begin{array}{l}\text { Isolation frequency } \\
\text { (capital cities) }\end{array}$ & $\% 2003$ & 24 & 0 & 29 & n.a. & STEM 2004 \\
\hline
\end{tabular}

The largest four Nordic companies - Vattenfall (Sweden), Fortum (Finland), Statkraft (Norway) and Sydfraft (Sweden) - have a significant presence in all three national markets. However, there is significant competition across the Nordic market as a whole. These four companies have market shares ranging from $47 \%$ to $19 \%$ in their own countries, but their shares of the whole Nordic market range from 17 to $8 \%{ }^{71}$

Interconnectors between the national transmission networks can take much but not all of the desired traffic. The result is that, for the most part, the countries have access to the price in the Nord Pool, and it is legitimate to talk of a 'Nordic market'. However, the capital cities in Norway and Finland (and other areas) are 'isolated' by transmission capacity constraints for around a quarter of the time, at which times different local prices apply as the markets are 'split'. The constituent markets are also characterised by varying degrees of dependency on hydro-electric power. Depending on annual climate conditions, the share of hydropower might range from about 12 to $25 \%$ in Finland and from 40 to $50 \%$ in Sweden, but in Norway is usually $99-100 \%$. (This compares with $1 \%$ or less in the UK.) The extent of hydro electricity has implications for market prices and risks, as noted in the text.

\section{A.3 Components of electricity prices in Sweden}

Table 13 sets out the various components of the total price of electricity, for the three main types of residential customers of different sizes. ${ }^{72}$ In round terms, the energy component accounts for 30 to 40 per cent of the total, network charges for 20 to 25 per cent, and various types of tax for about 40 per cent. ${ }^{73}$ The illustration is for Sweden: there would be some differences for the other two Nordic countries. ${ }^{74}$

\footnotetext{
${ }^{71}$ Bergman 2005 Table 2, citing Swedish Energy Agency. See also Lewis et al 2004 on the Nordic wholesale market and Olsen and Skytte 2003 on market power.

${ }^{72}$ About 24\% of all residential customers in Sweden have houses with electric heating, 30\% have homes or cottages without electric heating, and 44\% have apartments. The Electricity Year 2003, Swede Energy, Table 2, p. 13.

${ }^{73}$ STEM 2004, Table 1 p. 11, p. 24, Table 9 p. 25.

${ }^{74}$ Network charges seem to be a little higher in Finland and Denmark (around 25 ore/kWh) and higher still in Norway (about 30 ore $/ \mathrm{kWh}$ ). On the other hand, the energy tax is lower in Norway (10.3 ore $/ \mathrm{kWh}$ ) and Finland (6.3 ore/kWh) but much higher in Denmark (61.8 ore $/ \mathrm{kWh})$. In most other countries, not least the UK with VAT at $5 \%$, the proportion of energy taxes would be much lower.
} 
Table 13 Components of the total electricity price in Sweden 1 January 2004

\begin{tabular}{lllllll}
\hline Cost item & \multicolumn{2}{l}{$\begin{array}{l}\text { House with electric } \\
\text { heating }\end{array}$} & \multicolumn{2}{l}{$\begin{array}{l}\text { House without } \\
\text { electric heating }\end{array}$} & \multicolumn{2}{c}{ Apartment } \\
\hline & Ore/kWh & $\%$ & Ore/kWh & $\%$ & Ore $/ \mathrm{kWh}$ & $\%$ \\
Energy price & 48.0 & 40 & 50.7 & 35 & 55.8 & 31 \\
Network charges & 22.1 & 18 & 40.1 & 27 & 46.2 & 26 \\
Electricity tax & 24.1 & 20 & 24.1 & 16 & 24.1 & 14 \\
Electricity certif. & 2.2 & 2 & 2.2 & 2 & 2.2 & 1 \\
VAT @ 25\% & 24.1 & 20 & 29.3 & 17 & 32.1 & 18 \\
Total price & 120.5 & 100 & 146.4 & 100 & 178.5 & 100 \\
\hline
\end{tabular}

For a variety of reasons, electricity prices in Sweden have been increasing over the last two decades. For a large domestic household, the total price increased from a low of under 45 ore $/ \mathrm{k} / \mathrm{wh}$ in 1988 to about 65 ore $/ \mathrm{kWh}$ in $1998 .{ }^{75}$ Deregulation led to competitive wholesale trading and to steadily falling wholesale prices after 1996, broken by spot price increases in 2001 and $2002 .{ }^{76}$ Network charges increased from 1997 to 2004: by about $4 \%$ for a house with electric heating, and by 11 or $12 \%$ for smaller homes. There were also increases in the electricity tax, which more than doubled from 1996 to 2004, and electricity certificates were introduced in 2003 to pay for renewable energy. The net effect was that the total energy price for a large household rose from about 55 ore/kWh in 1995 to about 65 ore/kWh in 1998, fell back to 60 ore/kWh in 2000 and early 2001 , but by end 2003 was nearly 110 ore/kWh, roughly double what it had been in $1995 .^{77}$ By early 2005 the price had fallen back to about 75 ore $/ \mathrm{kWh}$.

Energy prices have also become slightly more differentiated over this period. Compared to the average house without electric heating (using $5000 \mathrm{kWh} /$ year), the discount for a house with electric heating $(20,000 \mathrm{kWh} /$ year $)$ has increased from 18 to 22 per cent, while the premium for an apartment $(2000 \mathrm{kWh} /$ year $)$ has increased from under 10 to 12 per cent. This presumably reflects in large part the increased proportion of the bill now accounted for by network charges and electricity taxes, as well as the force of competition in relating prices more closely to the underlying costs of serving each type of customer.

\footnotetext{
${ }^{75}$ Energy in Sweden Some Facts and Figures, Svensk Energi, May 2005 at www.svenskenergi.se.

${ }^{76}$ STEM 2004, pp 24-26.

${ }^{77}$ Svensk Energy May 2005. Estimated total prices in January 1997 were 71.1, 91.6 and 100.3 ore $/ \mathrm{kWh}$, hence increases of $69 \%, 60 \%$ and $78 \%$ for the three types of residential housing, respectively. STEM 2004 as before.
} 


\section{References}

Adib, Parviz and Jay Zarnikau (2006) "Texas: the most robust competitive market in North America", in Sioshanshi and Pfaffenburger (2006).

Amundsen Eirik S and Lars Bergman (2003) "The deregulated electricity markets in Norway and Sweden: a tentative assessment", in Glachant and Finon (2003), 110-132.

Baldick, Ross and Hui Niu (2005) "Lessons Learned: The Texas Experience" in Griffin and Puller (2005), pp. 182-226

Bergman, Lars (2002) "The Nordic electricity market - continued success or emerging problems?" Swedish Economic Policy Review, 9, 51-88.

Davies, Steve, Catherine Waddams Price and Laurence Matthieu (2005) "Non-linear pricing as a means of differentiating the product: residential electricity markets in the UK", presented at conference The Economics of Electricity Markets, Toulouse, June 2-3. (work in progress).

Energy Market Authority (2003) Annual Report 2003, Helsinki, Finland.

Giulietti, M, J Otero and M Waterson (2004), "Supply competition and price behaviour in the UK electricity supply industry", Centre for Management under Regulation, University of Warwick Discussion paper.

Giulietti, M, C Waddams Price and M Waterson (2006) "Consumer choice and industrial policy: a study of UK energy markets", Economic Journal, forthcoming.

Energy Market Authority (2004) Annual Report 2004, Helsinki, Finland.

Von der Fehr, Nils-Henrik M, Eirik S Amundsen and Lars Bergman (2005) "The Nordic Market: signs of stress?", The Energy Journal, Special issue on European energy liberalization.

Von der Fehr, Nils-Henrik M, Eirik S Amundsen and Lars Bergman (2006) "The Nordic Market" in Sioshanshi and Pfaffenburger (2006).

Glachant, Jean-Michel and Dominique Finon (eds.) (2003) Competition in European Electricity Markets: A Cross country Comparison, Cheltenham UK and Northampton MA USA: Edward Elgar.

Griffin, James M and Steven L Puller (eds) (2005), Electricity Deregulation: Choices and Challenges, Chicago and London: University of Chicago Press.

Green, Richard (2005) "Restructuring the Electricity Industry in England and Wales", in Griffin and Puller (2005), pp. 98-144. 
Green, R. and McDaniel, T. (1998), 'Competition in Electricity Supply: Will '1998 Be Worth It?’ Fiscal Studies, Vol.19, No.3, pp.273-93.

Joskow, Paul (2000a) "Why do we need electricity retailers? You can get it cheaper wholesale", http://econ-www.mit.edu/faculty/pjoskow/files/RETAILV2.pdf

Joskow, Paul (2000b) "Deregulation and regulatory reform in the US electric power sector", in Sam Peltzman and Clifford Winston (eds) Deregulation of Network Industries; What's Next, Washington DC: AEI-Brookings Joint Centre for Regulatory Studies, pp. 113-188.

Joskow, Paul (2005) "The difficult transition to competitive electricity markets in the United States" in Griffin and Puller (2005) pp. 31-97.

Joskow, Paul (2006) "Electricity sector liberalisation: lessons learned from crosscountry studies", in Sioshanshi and Pfaffenburger (2006).

Hjalmarsson, Lennart (2002) "Comment on David Newbery: Regulatory challenges to European electricity liberalisation”, Swedish Economic Policy Review, 9, 45-9.

Lewis, Philip E, Tor A Johnsen, Teemu Narva, Salma Wasti (2004) Analysing the relationship between wholesale and end-user prices in the Nordic electricity market, Report to Ministry of Trade and Industry in Finland, VaasaEmg, University of Vaasa, Helsinki, April, released 17 May.

Littlechild. Stephen C (2001a) "Retail competition - the benefits must not be underestimated", Power UK, 89, July, pp. 17-25, and "Reply to Graham Shuttleworth", Power UK, 91, September, pp.44-5.

Littlechild. Stephen C (2001b) "Competition and Regulation in the UK Electricity Industry (with a brief look at California)", Journal of Applied Corporate Finance, Volume 13, Number 4, Winter, pp. 21-38.

Littlechild, Stephen C (2002) "Competition in Retail Electricity Supply", Journal des Economistes et des Etudes Humaines, 12 (2/3), July/September, 353-376. (reprinted in Cambridge Working Papers in Economics CWPE 0227, CMI Electricity Project EP 09 at http://www.electricitypolicy.org.uk/pubs/wp.html).

Littlechild. Stephen C (2003a) "Wholesale Spot Price Pass-Through", Journal of Regulatory Economics, vol 23, no 1, January, pp. 61-91.

Littlechild. Stephen C (2003b) Electricity: Regulatory Developments Around the World, (Beesley Lecture 9 October 2001), in C Robinson (ed) Competition and Regulation in Utility Markets, London: Institute of Economic Affairs and London Business School, pp 61-87.

Littlechild, Stephen C (2004) "UK domestic energy contracts, the 28 day rule, and experience in Sweden", Cambridge Working Papers in Economics CWPE 0431, CMI Working Paper 45, 26 May, at http://www.electricitypolicy.org.uk/pubs/wp.html. 
Littlechild, Stephen C (2005a) Smaller suppliers in the UK domestic electricity market: experience, concerns and policy recommendations, Electricity Policy Research Group Miscellaneous Publications, 29 June, at http://www.electricitypolicy.org.uk/pubs/wp.html.

Littlechild, Stephen C (2005b) "Residential energy contracts and the 28 day rule", Utilities Policy (forthcoming).

Midttun, Atle, Joar Handeland and Terje Omland (2003) "The Nordic public ownership model under transition to market economy: the case of electricity" in Glachant and Finon (2003), pp. 133-166.

Newbery, David (2006), "Electricity liberalisation in Britain and the evolution of market design" in Sioshanshi and Pfaffenburger (2006).

Ofgem (2004) Domestic Competitive Market Review: A review document, April 2004, at www.ofgem.gov.uk.

Olsen, Ole Jess and Klaus Skyette (2003) "Competition and market power in Northern Europe" in Glachant and Finon (2003), pp. 169-192.

Salies, E. and C. Waddams Price (2004). "Charges, Costs, and Market Power: The Deregulated UK Electricity Retail Market.” The Energy Journal 25(3), 19-37.

Sioshansi, Perry and Wolfgang Pfaffenburger (eds.) (2006) International experience in restructured electricity markets: What works, what does not, and why? Elsevier (forthcoming).

Swedish Energy Agency (2004) The Energy Market 2004, August, at www.stem.se

TEMO (2004) Byte av elleverantor: Den svenska elmarknaden efter elmarknadsreformen [Choice of electricity supplier: the Swedish electricity market after electricity market reform], Holsten [autumn] 2004, T-110698, Svensk Energi and Temo AB, 28 October, at http://www.svenskenergi.se/media/underlag/prmo41103.pdf

Tschlamer, Taff (2006) "An assessment of competitive US retail markets" in Sioshanshi and Pfaffenburger (2006). 